\title{
Environmental Monitoring Report on the Status of Ground Water Beneath the Hanford Site
}

January-December 1975<smiles>[Te][Te]</smiles>

Prepared for the Energy Research and Development Administration under Contract $\mathbf{E}(45-1)$ : 1830 
NOTICE

This report was prepared as an account of work sponsored by the United States Covernment. Neither the United States nor the Energy Research and Development Administration, nor any of their employees, nor any of their contractors, subcontractors, or their employees, makes any warranty, express or implied, or assumes any legal liability or responsibility for the accuracy, completeness or usefulness of any imformation, apparatus, product or process disclosed, or represents that its use would not infringe privately owned rights.

\title{
PACIFIC NORTHWEST LABORATORY
}

\author{
operated by
}

BATTELLE

for the

ENERGY RESEARCH AND DEVELOPMENT ADMINISTRATION

Under Contract E(45-1)-1830

\author{
Printed in the United States of America \\ Available from \\ National Technical Information Service \\ U.S. Department of Commerce \\ 5285 Port Royal Road \\ Springtield, Virginia 22151 \\ Price: Printed Copy 55.00; Microfiche 52.25
}




\section{3}

ENV IRONMENTAL MONITORING REPORT ON THE STATUS OF GROUND WATER BENEATH THE HANFORD SITE JANUARY-DECEMBER 1975

D. A. Myers

J. J. Fix

P. J. Blumer

J. R. Raymond

V. L. McGhan

E. L. Hilty
Environmental Evaluations Section Environmental Evaluations Section Environmental Evaluations Section Resources Systems Section Resources Systems Section Resources Systems Section 


\section{PREFACE}

This report is one of a series prepared annually to provide an evaluation of the status of ground-water contamination resulting from Hanford onsite discharges. This issue covers the data collected January through December 1975. The maps of the contamination plumes and the data tables are provided to allow comparison with previous report periods. The previous report in this series was BNWL-1970. (1) An additional parameter included in this report is the distribution of ground-water temperatures beneath the site. 


\section{CONTENTS}

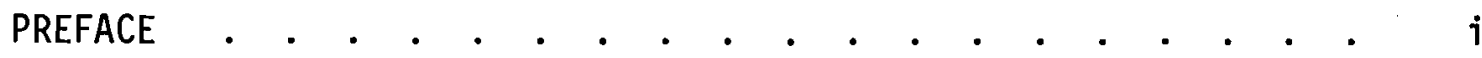

INTRODUCTION • • • •

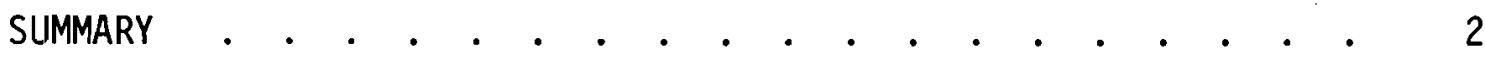

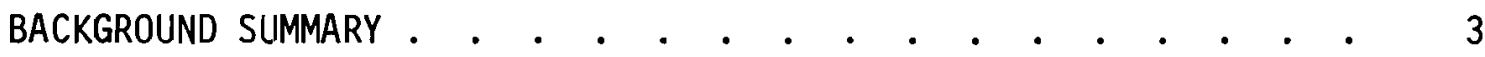

Plant Operations . . . . . . . . . . . . . . 3

Disposition of Wastes . . . . . . . . . . . . . 3

Monitoring and Wells . . . . . . . . . . . . 5

Sampling and Analysis . . . . . . . . . . . . 6

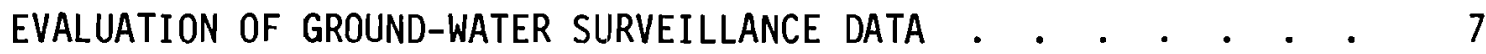

Gross Beta $\left(\beta_{t}\right)$ Concentration in the Unconfined Ground Water 9

Tritium $\left({ }^{3} \mathrm{H}\right)$ Concentration in the Unconfined Ground Water . 12

Nitrate $\left(\mathrm{NO}_{3}^{-}\right)$Concentration in the Unconfined Ground Water . 16 ADDITIONAL RADIOCONTAMINANTS IN THE UNCONFINED GROUND WATER • 17

Status of Contamination in the Lower Aquifer

(Confined Zones). . . . . . . . . . . . . . 21

Thermal Contamination . . . . . . . . . . . . 22

QUALITY CONTROL • • • • • • • • • • • • • • • • • • • • 22

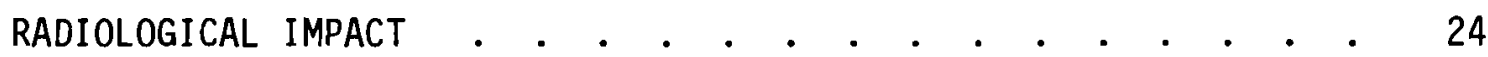

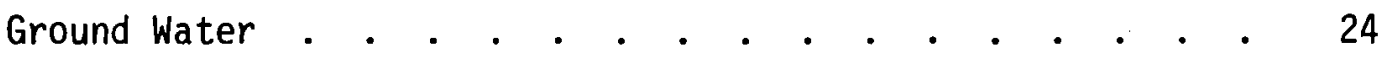

Columbia River. . . . . . . . . . . . . . . 24

REFERENCES • • • • • • • • • • • • • • • • • • • 26

APPENDIX A • . . . . . . . . . . . . . . . . $A-1$

APPENDIX B . . . . . . . . . . . . . . . . . B-1

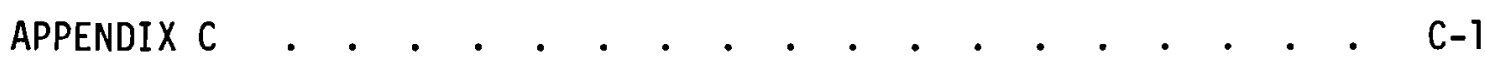

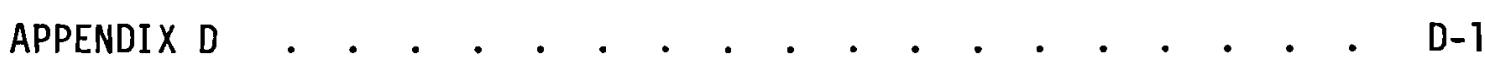




\section{LIST OF FIGURES}

1 Hanford Site. . . . . . . . . . . . . . . . . 4

2 Gross Beta Concentrations (Calculated as ${ }^{106} \mathrm{Ru}$ ), December 1975 See back page pocket

3 Tritium Concentrations, December 1975 See back page pocket

4 Nitrate Concentrations, December 1975 See back page pocket

5 We11 699-15-26 Concentration History (Tota1 Beta) . . . . . 10

6 We11 699-20-20 Concentration History (Total Beta) . . . . . 11

7 We11 699-35-66 Concentration History (Tritium) . . . . . . 13

8 We11 699-8-25 Concentration History (Tritium). . . . . . . 14

9 We11 699-2-3 Concentration History (Tritium) . . . . . . . 15

10 Well 699-27-8 Concentration History (Nitrate) . . . . . . . 18

11 Well 699-17-5 Concentration History (Nitrate). . . . . . . 19

12 Wel1 699-8-25 Concentration History (Nitrate). . . . . . . 20

13 Temperature Distribution, Nov-Dec 1975 See back page pocket

\section{LIST OF TABLES}

1 Lower Analytical Detection Limit and Applicable CG or DWS . . . 7

2 Numerical Data on the Routine Ground-Water Monitoring Program - CY-1975. . . . . . . . . . . . . . 8

3 Iodine-129 Analyses from Selected Deep Wells on the Hanford Site, June 1975 . . . . . . . . . . . . . . 21

4 Comparative Analyses; Lower versus Upper Aquifer . . . . . . 21

5 Comparison of Analytical Results Between Laboratories . . . . 23 


\section{$\underline{\text { INTRODUCTION }}$}

Surveillance of ground water on the Hanford Site is one facet of the comprehensive Environmental Monitoring Program designed to evaluate existing and potential pathways of contaminant exposure from project operations. Objectives of the Ground-Water Monitoring Program, conducted by Battel1eNorthwest for ERDA, are to measure and report the concentration and distribution of radioactive and chemical constituents in the ground water, determine the movement and transport of contaminants with time, and to determine the impact on man's environs.

A11 routine ground-water samples were taken by the Radiation Monitoring Section and were analyzed by the Technical Analysis Section as part of the Hanford Environmental Surveillance Program conducted by the Environmental Evaluations Section of Battelle-Northwest. Special samples for analysis by the U.S. Geological Survey were collected by the Resources Systems Section of BNW.

The Atlantic Richfield Hanford Company (ARHCO), ERDA's prime contractor for chemical processing and waste management activities on the Hanford site, has responsibility for operations within the 200 Areas. ARHCO conducts a Comprehensive Ground-Water Sampling and Analys is Program within the 200 Areas. Data obtained from the ARHCO program, except for a few analyses, are not included in this report. 


\section{SUMMARY}

Evaluation of the Gross Beta $\left(\beta_{t}\right)$, Tritium $\left({ }^{3} \mathrm{H}\right)$, and Nitrate $\left(\mathrm{NO}_{3}^{-}\right)$concentrations in ground water sampled from near the surface of the unconfined ground-water system during 1975 indicates that zones of contamination extend in an easterly and southeasterly direction from the 200-E Area, as has been observed in the past. (1) Tritium and $\mathrm{NO}_{3}^{-}$ion concentrations above background levels continue to be observed along the Columbia River in the vicinity of the 100 Areas. Ground water in the vicinity of the 300 Area continues to show $\mathrm{NO}_{3}^{-}$ion and uranium concentrations above background levels. Gross Beta activity in the ground water beneath the 100 Areas was detectable only in the 100-N Area from effluent discharged to the 1301-N Crib and in the vicinity of 100-B Area. Analyses for other radionuclides such as ${ }^{90} \mathrm{Sr},{ }^{60} \mathrm{Co},{ }^{129} \mathrm{I},{ }^{137} \mathrm{Cs}$ and ${ }^{106} \mathrm{Ru}$, show that they are present in various locations outside the 200 Areas but only in very low concentrations. Generally concentrations of radionuclides outside the 200 Areas are less than $10 \%$ of Concentration Guide. (2)

Nitrate ion concentrations greater than the Public Health Service (PHS) and Environmental Protection Agency (EPA) recommended drinking water standard ${ }^{(3)}$ of $45 \mathrm{mg} / \ell$ continue to be observed in the ground water adjacent to and within the 200 Areas; in the vicinity of the $100-\mathrm{F}$ and $\mathrm{N}$ areas; and in the eastcentral part of the Hanford Site. Ground water from these zones is not consumed by human beings or other animals.

Configuration and concentration of ground-water contamination has changed only slightly from the past reporting period. Additional data points have resulted in expansion of some zones of contamination. 
BACKGROUND SUMMARY

\section{PLANT OPERATIONS}

Operations on the Hanford site since 1944 have resulted in ground disposal of large volumes of low-level and intermediate-level liquid radioactive wastes. Figure 1 shows the location and configuration of the site. Most of the liquid wastes have been disposed to the ground at the chemical separation areas (200 Areas) located on a plateau near the center of the site. Smaller amounts of wastes have been released at the reactor sites (100 Areas) located adjacent to the Columbia River, and at the laboratory and fuel fabrication area (300 Area). Only one reactor and associated disposal facility (100-N Area) is currently in operation. Ground disposal of 1 iquid waste has been greatly reduced in the past several years due to the deactivation of all Hanford reactors (except $N$ Reactor) with the resulting decrease in reactor fuel processing, coupled with improved treatment of several intermediate-level waste streams.

\section{DISPOSITION OF WASTES}

Liquid wastes disposed to the ground percolate laterally and downward through the 150 to 300 feet of unconsolidated glaciofluvial and lacustrine sands, silts and gravel overlying the ground-water table. As the wastes move through the sedimentary earth materials, adsorption and ion exchange reactions take place between the minerals in the sediments and the materials in the waste water. Some of the longer lived and more hazardous radionuclides such as strontium-90 $\left({ }^{90} \mathrm{Sr}\right)$, cesium-137 $\left({ }^{137} \mathrm{Cs}\right)$ and plutonium-239 $\left({ }^{239} \mathrm{Pu}\right)$ have favorable ion exchange characteristics and are effectively removed from the water. Some radionuclides such as ruthenium-106 ( $\left.{ }^{106} \mathrm{Ru}\right)$, cobalt-60 $\left({ }^{60} \mathrm{Co}\right)$, technetium-99 $\left({ }^{99} \mathrm{TC}\right)$, tritium $\left({ }^{3} \mathrm{H}\right)$ and nonradioactive materials such as nitrate $\left(\mathrm{NO}_{3}^{-}\right)$do not have good ion exchange characteristics and move through the ground at varying rates to eventually enter the ground water. When the contaminants enter the water table, they move in a general down gradient direction with the ground water. As the radionuclides move in the ground water, their concentration is reduced by radioactive decay, ion exchange, diffusion and hydrodynamic dispersion. 


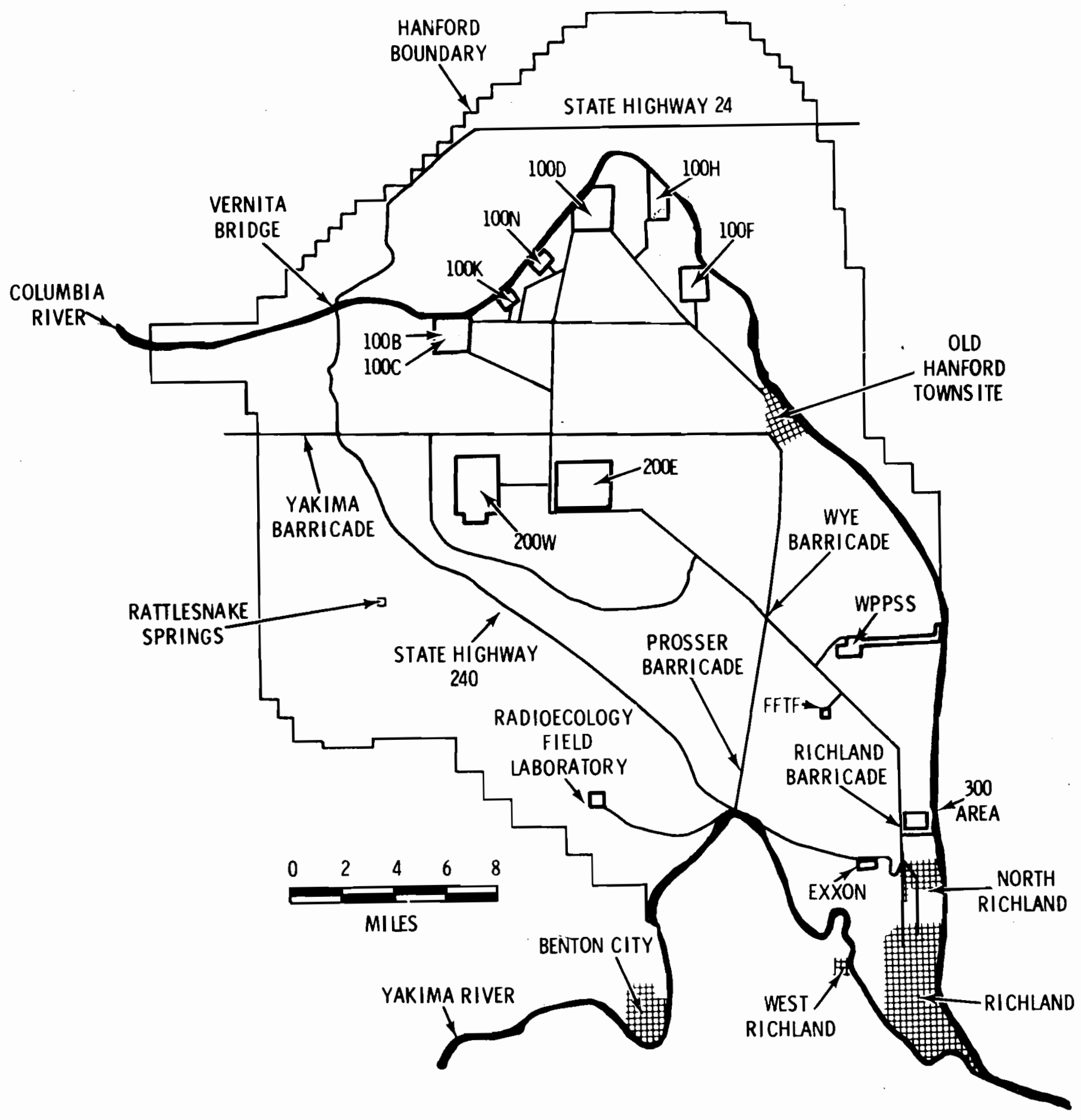

FIGURE 1 Hanford Site 
Disposal of more than 130 billion gallons of process cooling water and about 8 billion gallons of intermediate-level radioactive waste over the past 30 years has profoundly changed the water table. Ground-water mounds have been created near each of the chemical processing areas and in the 100-N Reactor Area from discharge of waste water. Ground-water levels have changed continuously over the years, depending upon variations in volumes and locations of waste water discharged to the ground. Movement of the ground water and associated contaminants also have changed with time reflecting the variation in waste water discharge.

\section{MONITORING AND WELLS}

Over 700 cased monitoring wells ${ }^{(4)}$ have been drilled to water since the beginning of disposal operations at Hanford. The structures provide access for obtaining water samples and for conducting in-well investigations. Some of the wells are drilled to basalt bedrock, others are drilled to the first semi-previous layer below the water table, and still others are drilled only a few tens of feet below the water table in the unconfined aquifer. Most of the wells were drilled as multipurpose structures to obtain geologic and hydrologic information as well as water quality data.

To provide an ideal structure for monitoring purposes, a well should be perforated throughout its length below the water table and the water in the aquifer should flow through the casing normal to the well at all depths. However, since the heterogeneity of the sediments beneath the Hanford site prevent this, each well structure must be evaluated individually as a monitoring facility.

Two hundred and twenty-two wells were used in the 1975 routine Ground-Water Monitoring Program; 875 we11 water samples were taken to provide 1864 analytical results for use in evaluating the effects of site operations on the ground water. These figures do not include ARHCO's monitoring efforts in the 200 Areas. 


\section{SAMPLING AND ANALYSIS}

Sampling frequency varies from monthly to semiannually, depending on well location and the analyzed constituent. Most of the ground-water samples are collected near the water surface of the unconfined aquifer by lowering a glass bottle enclosed in a steel bail into the water. Usually, when contamination appears in a project well, the highest concentration is observed at the surface of the water table. A study to define vertical stratification of contaminants in the ground water has been initiated. At a few locations where appropriate well structures are available, samples are obtained from the confined aquifer zones. Submersible sampling pumps are being installed in key wells to obtain a more representative sample of the water in the aquifer adjacent to the well than is provided by a small-volume dipped sample.

The radionuclides represented by $\beta_{t}$ measurement (calculated as ${ }^{106} \mathrm{Ru}$ ) and $3_{\mathrm{H}}$, as well as $\mathrm{NO}_{3}^{-}$ion are readily transported in the ground water with little decrease in concentration due to adsorption or ion exchange. They also can be detected in low concentrations in the ground water relative to their respective Concentration Guides (CG) ${ }^{(2)}$ or drinking water standards (DWS). (3) Therefore, these substances are used as primary tracers to monitor the movement of contaminated ground water. In addition to $\mathrm{B}_{t},{ }^{3} \mathrm{H}$, and $\mathrm{NO}_{3}^{-}$, samples from selected wells are routinely analyzed at less frequent intervals for the radionuclides ${ }^{90} \mathrm{Sr},{ }^{137} \mathrm{Cs}$, and ${ }^{60} \mathrm{Co}$. Total alpha-emission is also determined. Selected samples are analyzed by gamma ray spectrometry. Ground water from several wells is analyzed for chemical water parameters to monitor broader changes in water quality. Analyses for uranium $\left({ }^{238} U\right)$, fluoride $\left(F^{-}\right)$ and hexavalent chromium ion $\left(\mathrm{Cr}^{+6}\right)$ are done on selected ground-water samples in and adjacent to the 300 Area because the fuel fabrication waste water disposed at this site contains these contaminants. Standard radiometric and chemical methods are used to analyze the routine ground-water samples. We11 water analyses are obtained frequently from throughout the Hanford site. other radionuclides, such as ${ }^{129} \mathrm{I}$ and ${ }^{99} \mathrm{Tc}$, have been detected in the ground water beneath the Hanford site. These radionuclides also make excellent tracers of ground-water contamination, and are used to a limited extent, but they generally occur in very low concentrations. 


\section{EVALUATION OF GROUND-WATER SURVEILLANCE DATA}

Radionuclide concentrations in the ground water beneath Hanford are evaluated in terms of their respective Concentration Guides (CGs) while nonradioactive materials are compared to the U.S. Public Health Service recommended drinking water standards (DWS). While these guides pertain to drinking water, at present no ground water from zones having concentrations greater than the standards is used for human or animal consumption. However, the comparison provides a conservative method of evaluating the potential significance of most water-borne materials. The Concentration Guides used in this report are those which apply to uncontrolled areas. Table 1 shows the detection limit and applicable CG or DWS for various materials analyzed for under the routine Ground-Water Moni.toring Program.

TABLE 1 Lower Analytical Detection Limit and Applicable CG or DWS

\begin{tabular}{|c|c|c|}
\hline Analysis & Detection Limit & CG or DWS \\
\hline$\beta_{t}\left(\right.$ as $\left.{ }^{106} R u\right)$ & $0.08^{(a)}$ & $N A^{(b)}$ \\
\hline Gross Alpha (as ${ }^{239} \mathrm{Pu}$ ) & $0.017^{(a)}$ & ${ }_{N A}(b)$ \\
\hline $3_{\mathrm{H}}$ & $1.0^{(\mathrm{a})}$ & $3000^{(a)}$ \\
\hline${ }^{60} \mathrm{Co}$ & $0.02^{(a)}$ & $30^{(a)}$ \\
\hline${ }^{90} \mathrm{Sr}$ & $0.03^{(a)}$ & $0.3^{(a)}$ \\
\hline${ }^{106}{ }_{\mathrm{Ru}}$ & $0.06^{(a)}$ & $10^{(a)}$ \\
\hline${ }^{125} \mathrm{Sb}$ & $0.06^{(a)}$ & $100^{(a)}$ \\
\hline${ }^{131} \mathrm{I}$ & $0.0 i^{(a)}$ & $0.3^{(a)}$ \\
\hline${ }^{137} \mathrm{CS}$ & $0.02^{(a)}$ & $20^{(a)}$ \\
\hline $\mathrm{NO}_{3}^{-}$ & $0.5^{(c)}$ & $45^{(c)}$ \\
\hline $\mathrm{F}^{-}$ & $0.08^{(c)}$ & $1.8^{(\mathrm{c})}$ \\
\hline $\mathrm{Cr}^{+6}$ & $3^{(c)}$ & $50^{(\mathrm{d})}$ \\
\hline
\end{tabular}

(a) $\mathrm{p} \overline{\mathrm{C}} \overline{\mathrm{i} / \mathrm{m} \ell}$

(b) NA - Not Applicable. Significance of contaminations

determined by specific radionuclide analysis.

(c) $\mathrm{mg} / \mathrm{l}$

(d) $\mu g / \ell$ 
Figures 2, 3 and 4 (in the pocket on back page) are maps that show the configuration and concentration of $\mathrm{B}_{t}, 3_{\mathrm{H}}$ and $\mathrm{NO}_{3}^{-}$, respectively, in the unconfined ground water beneath the Hanford site for $\mathrm{CY}-1975$. The isopleths on the map show concentration zones rather than discrete concentration contours because the data do not justify the display of concentration isopleths in more detail. Data from waste disposal operations and groundwater contamination in the 200 Areas are not included in this report. However, data from the 200 Areas were used to provide continuity for the maps.

Appendix A contains tabular analytical data for $\mathrm{CY}-1975$ on average, maximum and minimum concentrations of the primary tracers (gross beta, tritium and nitrate).

Appendix $B$ contains data on routine analyses for materials other than the primary tracers. Appendix $C$ contains results of ground-water analyses made for quality assurance or other special purposes during 1975. An effort to establish the chemistry of the ground water beneath the site has resulted in data concerning a broad spectrum of chemical constituents. Appendix $D$ shows the results of chemical and spectrochemical analyses of water from selected wells.

Table 2 shows the number of wells, areal distribution, number of samples and number of analyses involved in the routine Ground-Water Monitoring Program to provide the data shown in Appendixes $A$ and $B$.

TABLE 2. Numerical Data on the Routine Ground-Water Monitoring Program - $\mathrm{CY}-1975$

\begin{tabular}{|c|c|c|c|}
\hline Area & $\begin{array}{c}\text { Wells } \\
\text { Sampled } \\
\end{array}$ & $\begin{array}{l}\text { Number of } \\
\text { Samples }\end{array}$ & $\begin{array}{l}\text { Number of } \\
\text { Analyses }\end{array}$ \\
\hline 100 Areas & 19 & 60 & 166 \\
\hline 200 Areas & 38 & 191 & 324 \\
\hline 300 Area & 12 & 90 & 358 \\
\hline 600 Area & 148 & 524 & 996 \\
\hline other & $\underline{5}$ & 10 & 20 \\
\hline TOTAL & 222 & 875 & 1864 \\
\hline
\end{tabular}


GROSS BETA $\left(\beta_{t}\right)$ CONCENTRATION IN THE UNCONFINED GROUND WATER

Figure 2 shows the configuration and concentration of $\beta_{t}$ contamination in the unconfined ground water. Appendix A contains analytical data on the primary tracers for ground-water samples collected during CY-1975. The configuration of the $\beta_{t}$ plume is static and shows essentially no change over the previous reporting period. The plume extends southeasterly about $7.8 \mathrm{miles}$ from the 200 East Area. Concentrations within this plume in all locations external to the 200 East Area are less than $1.0 \mathrm{pCi} / \mathrm{ml}$ except for a smal1 zone near the northwest corner of the 200 East Area and near the southeast corner of the 200-W Area, where concentrations above the $1.0 \mathrm{pCi} / \mathrm{ml}$ leve1. Gross beta concentrations are decreasing in most locations throughout the plume. Figure 5 shows a graph of the $\beta_{t}$ concentration history for Well 699-15-26 which is located just south of the main plume. Gross beta concentrations have been decreasing at this location since about 1966 with an apparent half-life of 1.6 years. Figure 6 illustrates the gross beta history of Well 699-20-20. This well is currently showing gross beta values at the detection limit of $0.08 \mathrm{pCi} / \mathrm{ml}$. Both of these wells show that the plume is effectively decaying and decreasing in size.

In addition to the 200 Area plumes, $\beta_{t}$ contamination in the ground water is evident in the 100-N Reactor Area from liquid waste disposal to the 1301-N Crib. In the 100-B Area $\beta_{t}$ activities are due to past operations. In the 300 Area $\beta_{t}$ activity of the ground water is attributable to ${ }^{60}$ co from waste disposal facilities.

Gross beta activity in the ground water beneath the Hanford site has been calculated and reported for many years as ${ }^{106} \mathrm{Ru}$ (as was done for this report) since radiochemical analyses in the past have shown that this nuclide accounts for a large fraction of the $\beta_{t}$ activity. This evaluation may still be valid near the 200 Area disposal sites, but with a half-life of one year, decay reduces the proportion of ${ }^{106} \mathrm{Ru}$ in the mixture of betaemitters with distance (time) from the source areas (200 Areas). Initial evaluations to more fully characterize the concentration of beta-emitters that occur in ground water away from the 200 Areas (essentially southeast of the 200 East Area) indicate that ${ }^{60} \mathrm{Co}$ is the dominant nuclide. 


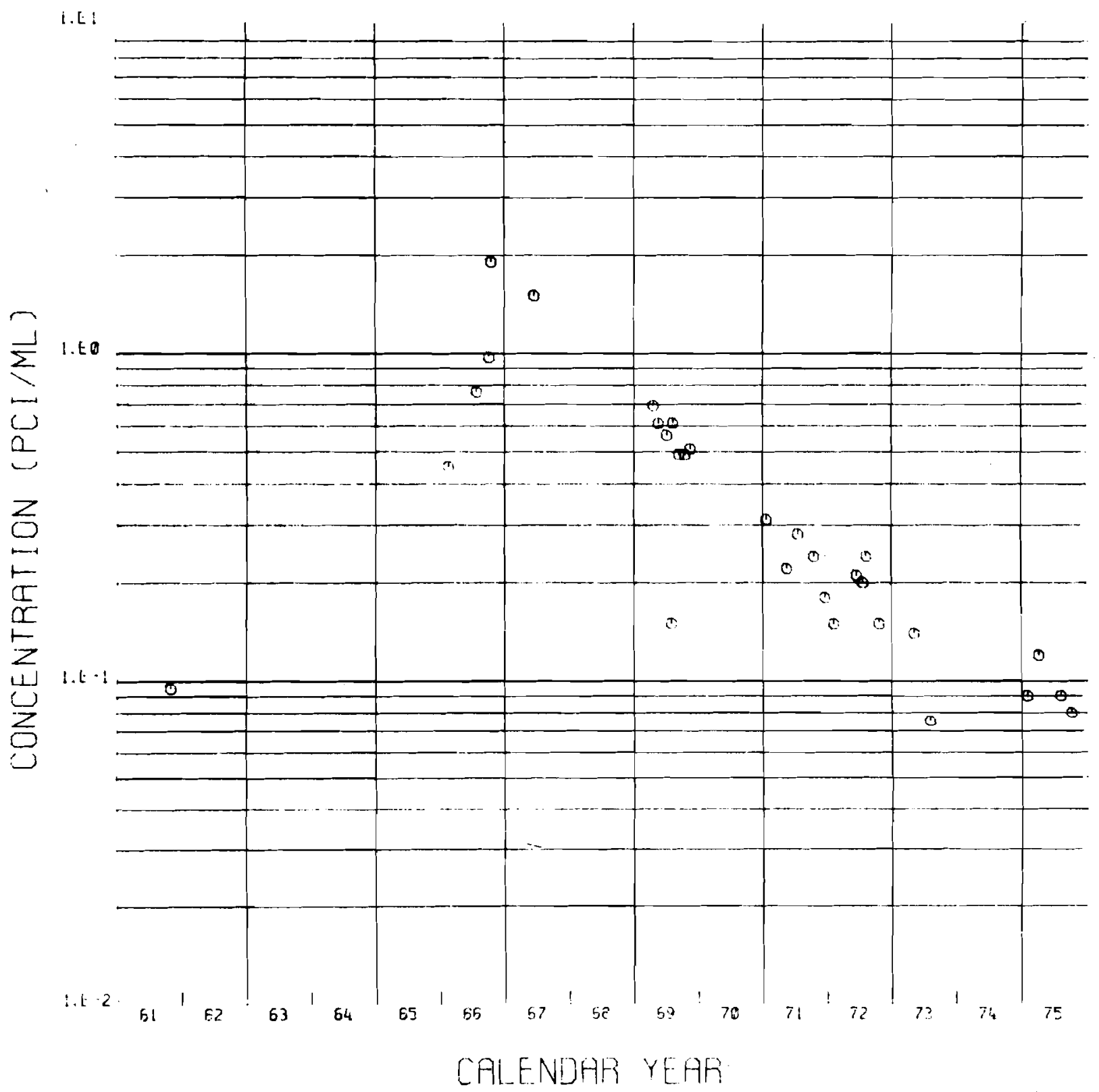

FIGURE 5. We11 699-15-26 Concentration History (Tota1 Beta) 


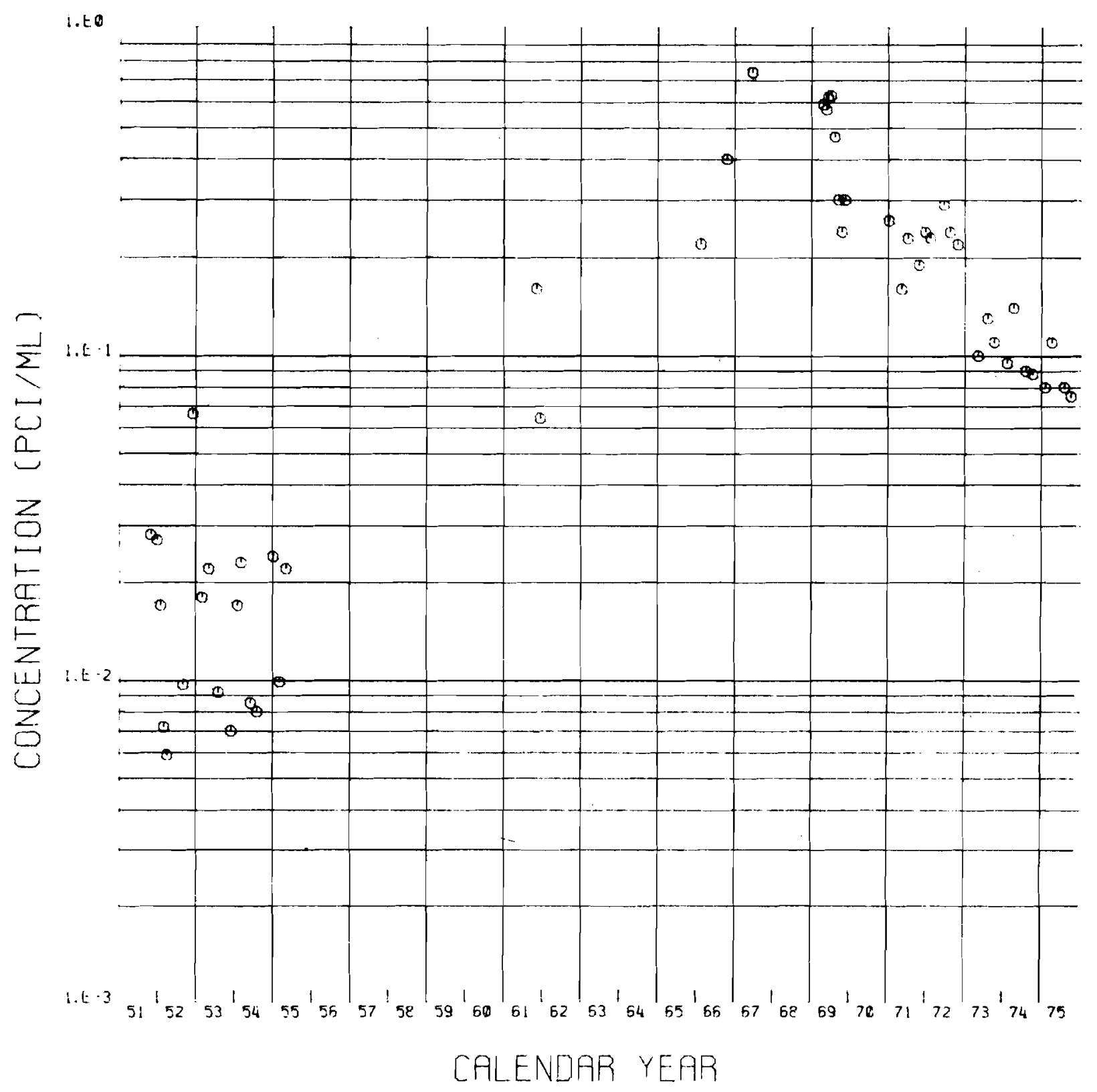

FIGURE 6. Well 699-20-20 Concentration History (Total Beta) 
Although analyses for $\beta_{t}$ are reported in $\mathrm{pCi} / \mathrm{ml}$ as ${ }^{106} \mathrm{Ru}$ and the evidence is that the predominant radionuclide is ${ }^{60} \mathrm{Co}$, the values do provide a screening process with adequate sensitivity to detect occurrence and changes in one parameter of radioactivity in the ground water beneath the Hanford site. It thus serves as a valuable tool in the monitoring program. A special study to ascertain the actual distribution and relative concentration of the $\beta$ contributors has been initiated.

TRITIUM $\left({ }^{3} H\right)$ CONCENTRATION IN THE UNCONF INED GROUND WATER

Figure 3 shows the configuration and concentration of ${ }^{3} \mathrm{H}$ in the unconfined ground water. Appendix A contains tabular data on the minimum, maximum and average concentrations for samples collected in 1975. Configuration of the ${ }^{3} \mathrm{H}$ plume from the $200 \mathrm{E}$ Area has changed little since the previous reporting period. The plume front has expanded toward the Columbia River in the vicinity of Well 699-40-1. Rehabilitation of this monitoring structure may account for the apparent increase in ${ }^{3} \mathrm{H}$ concentration. The 200-W Area contamination zone has remained essentially static as has the area north of Gable Mountain and Gable Butte. Concentrations of ${ }^{3} \mathrm{H}$ vary within these zones depending upon location.

Figure 7 is a graph of the ${ }^{3} \mathrm{H}$ concentration history for Well 699-35-66 which monitors the eastern edge of the 200-W Area plume. The graph of this well shows an increasing level of ${ }^{3} \mathrm{H}$ concentration, indicating that the plume is moving toward the well. Figure 8 shows a ${ }^{3} \mathrm{H}$ concentration history of Well 699-8-25. This graph shows that ${ }^{3} H$ levels have been decreasing over the past several years but now appear to be leveling off, indicating that the tritium front is probably maintaining its position relative to this structure. Figure 9 is a graph for well 699-2-3, located just south of the 200-E Area plume. Recent analyses for this well show an increase in $3_{H}$ levels, heralding the arrival of the plume. 


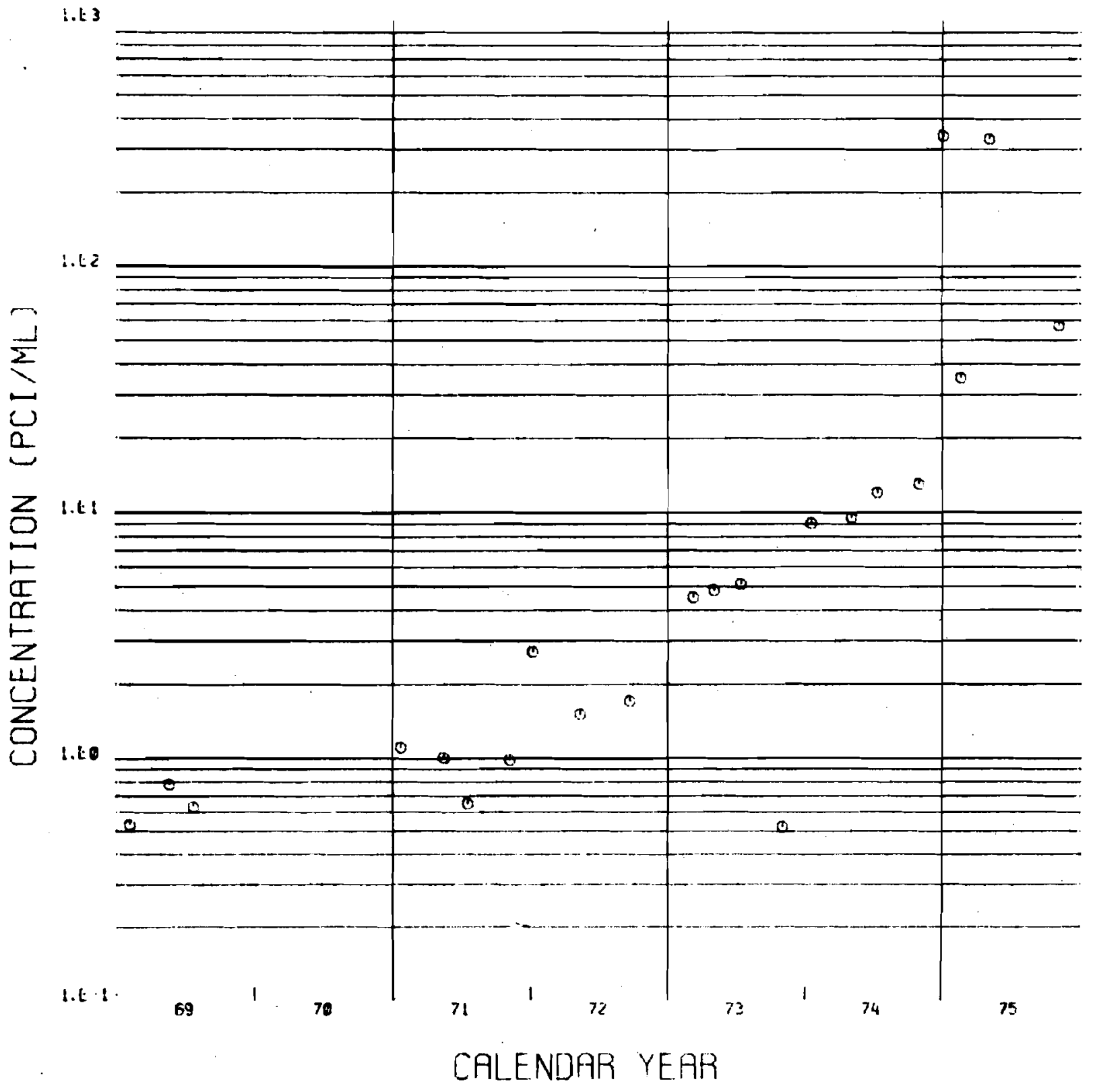

FIGURE 7. He11 699-35-66 Concentration History (Tritium) 


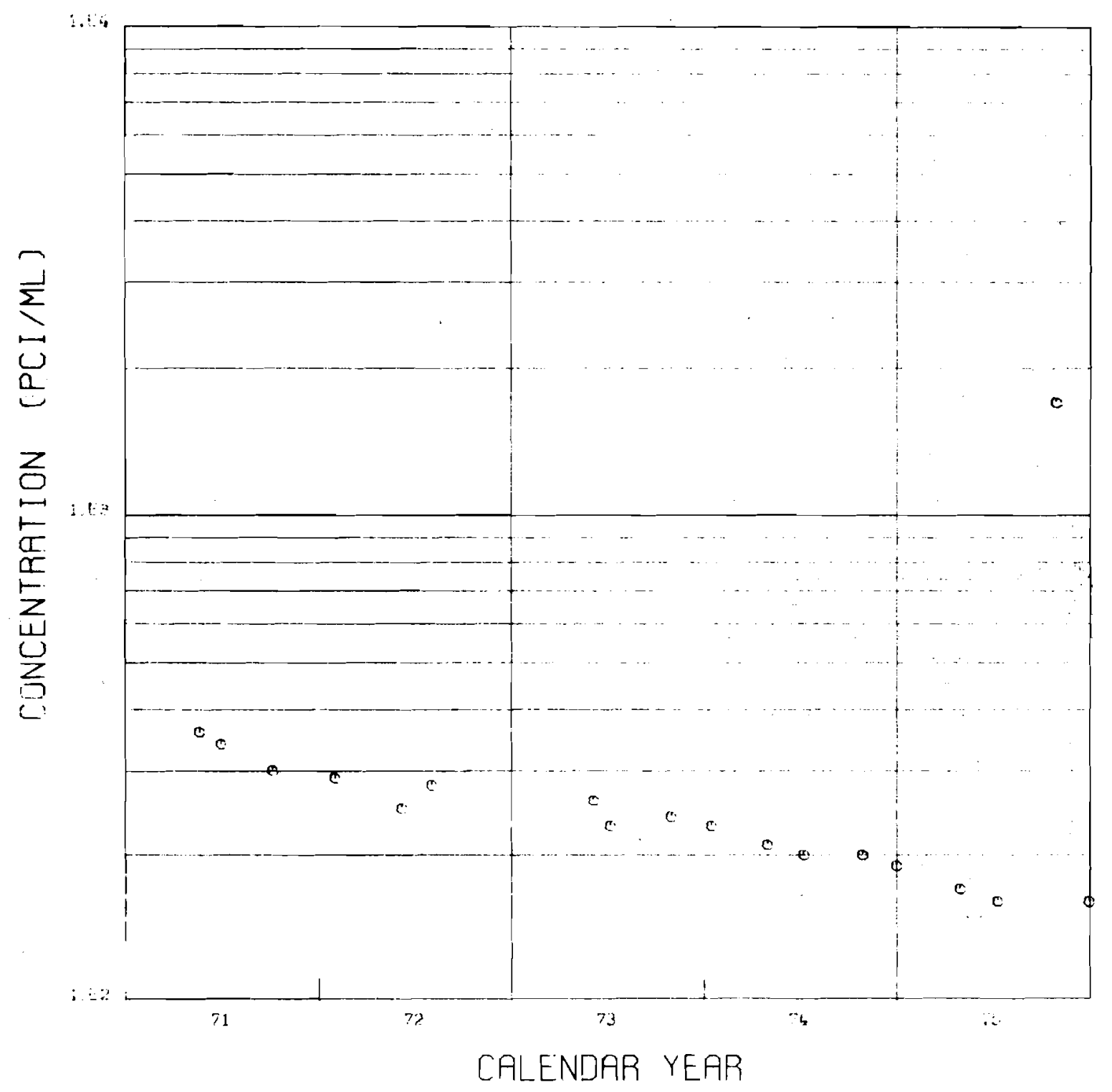

FIGURE 8. Wel1 699-8-25 Concentration History (Tritium) 


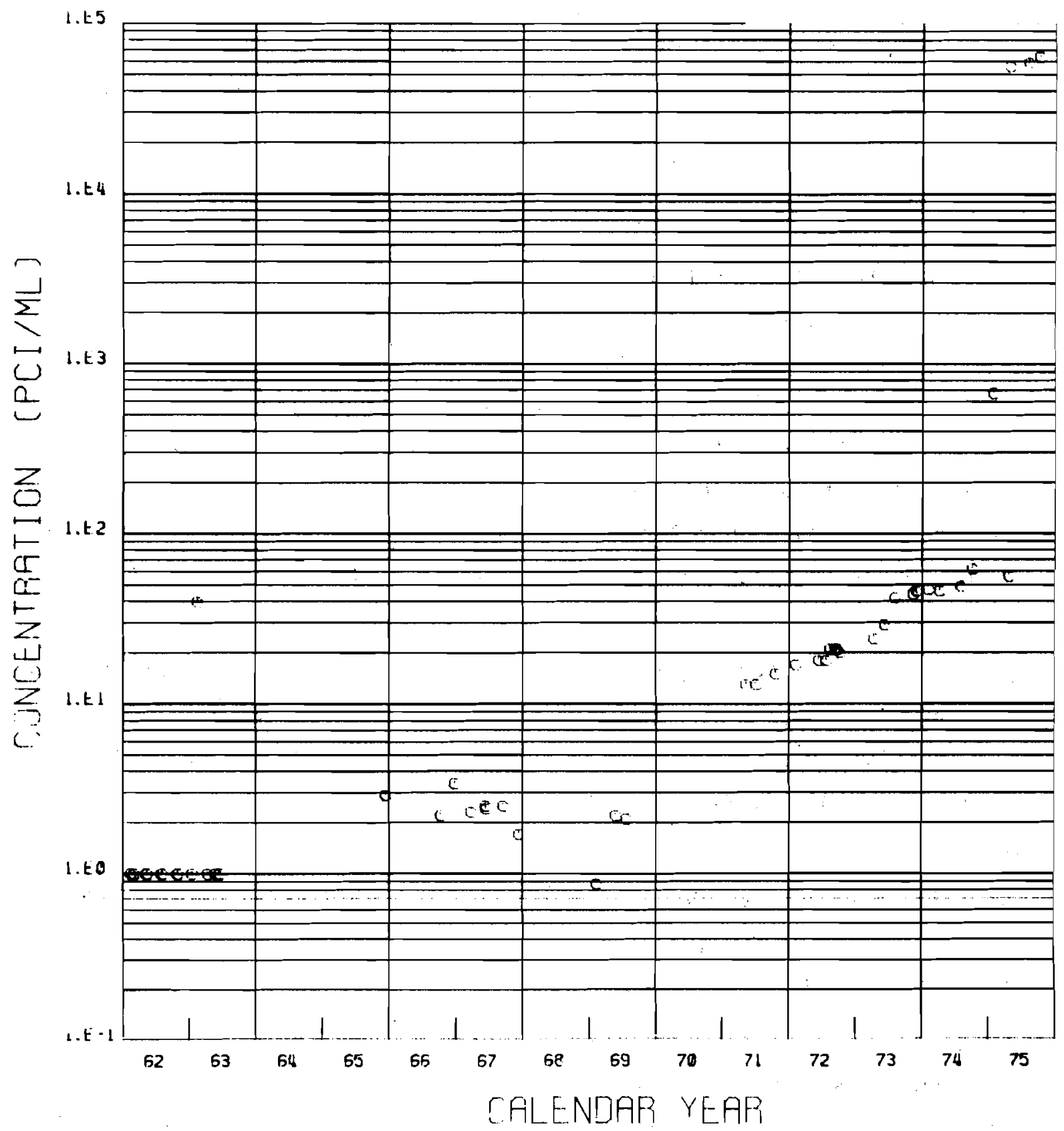

FIGURE-9. We11 699-2-3 Concentration History (Tritium) 
Residual ${ }^{3} \mathrm{H}$ is noted in the 100 Areas and contemporary ${ }^{3} \mathrm{H}$ occurs in and adjacent to the 100-N Area. The only location external to the 200 Areas where ${ }^{3} \mathrm{H}$ levels exceed $3000 \mathrm{pCi} / \mathrm{m}$ l $\mathrm{CG}$ is immediately adjacent to the southeast corner of the 200-W Area. Elsewhere ${ }^{3} \mathrm{H}$ is below the CG. Tritium travels through the soil column essentially unaffected by ion exchange or adsorption and thus provides the most representative tracer of ground-water movement.

\section{NITRATE $\left(\mathrm{NO}_{3}^{-}\right)$CONCENTRATION IN THE UNCONF INED GROUND WATER}

Figure 4 shows the concentration and configuration of $\mathrm{NO}_{3}^{-}$in the unconfined ground water. Appendix $\mathrm{A}$ contains $\mathrm{NO}_{3}^{-}$data; some additional data is contained in Appendix $C$. Extension of the nose of the plume in a southerly direction toward the 300 Area and enlargement of the zone of high concentration in the central portion of the plume are the only significant changes in the configuration of the plume since the last reporting period. The data indicate that concentrations of $\mathrm{NO}_{3}^{-}$are increasing in the vicinity of the FFTF and WPPSS sites as the plume moves toward the river in that vicinity.

Expansion of the isolated plume north of Gable Mountain and an apparent plume south of the $200 \mathrm{E}$ Area near the mouth of Cold Creek are indicated by additional data collected. The causes of these isolated zones are not known, but their isolation indicates that they are probably due to natural phenomena.

Considerable scatter is observed in the $\mathrm{NO}_{3}^{-}$data. Based upon the consistency of the ${ }^{3} \mathrm{H}$ and $\beta_{t}$ data, this scatter must be due to the nature of the ion or the analytic procedure.

Nitrate concentrations in the ground water (external to the 200 Areas) above the DWS of $45 \mathrm{mg} / \ell$ continue to be observed in the central part of the plume from 200 East Area, immediately north of the 200 East Area and in and adjacent to the 100-F Area. Small zones that show $\mathrm{NO}_{3}^{-}$concentrations in 
excess of $45 \mathrm{mg} / \mathrm{l}$ occur southeast of the 200 East Area (centered on Wel1s 699-34-42 and 34-41) and adjacent to the southeast corner of the 200 West Area.

Figure 10 is a graph of the $\mathrm{NO}_{3}^{-}$concentration history of Well 699-27-8. Nitrate levels in this well have increased over the past five years to the point where they averaged $47.3 \mathrm{mg} / \ell$ during 1975 . The increase in $\mathrm{NO}_{3}^{-}$ levels at this location indicates that the zone of high $\mathrm{NO}_{3}^{-}$ground water that has been present to the west of this area for several years, has extended to the east. Similarly the $\mathrm{NO}_{3}^{-}$concentration in Well 699-17-5 has increased (Figure 11) to the point where it averages $53.5 \mathrm{mg} / \ell$.

Figure 12 shows the $\mathrm{NO}_{3}^{-}$concentration history for We11 699-8-25. Nitrate levels in this well have held constant or decreased slightly, confirming the analyses for ${ }^{3} \mathrm{H}$ at this site.

\section{ADDITIONAL RADIOCONTAMINANTS IN THE UNCONFINED GOUND WATER}

Appendix B contains routine analyses made under the Ground-Water Monitoring Program for materials other than the primary tracers $\left(\mathrm{B}_{\mathrm{t}},{ }^{3} \mathrm{H}\right.$, and $\left.\mathrm{NO}_{3}^{-}\right)$. Analyses for Iodine-129 ( $\left.{ }^{129} I\right)$ which were made as part of a special study are included in Table 3. Iodine-129 is an excellent tracer of ground-water movement, however the analyses are extremely difficult and time consuming. None of the analyses show radionuclide concentrations in excess of the concentration guides for mixtures as set forth in ERDA Manual Chapter 0524. 


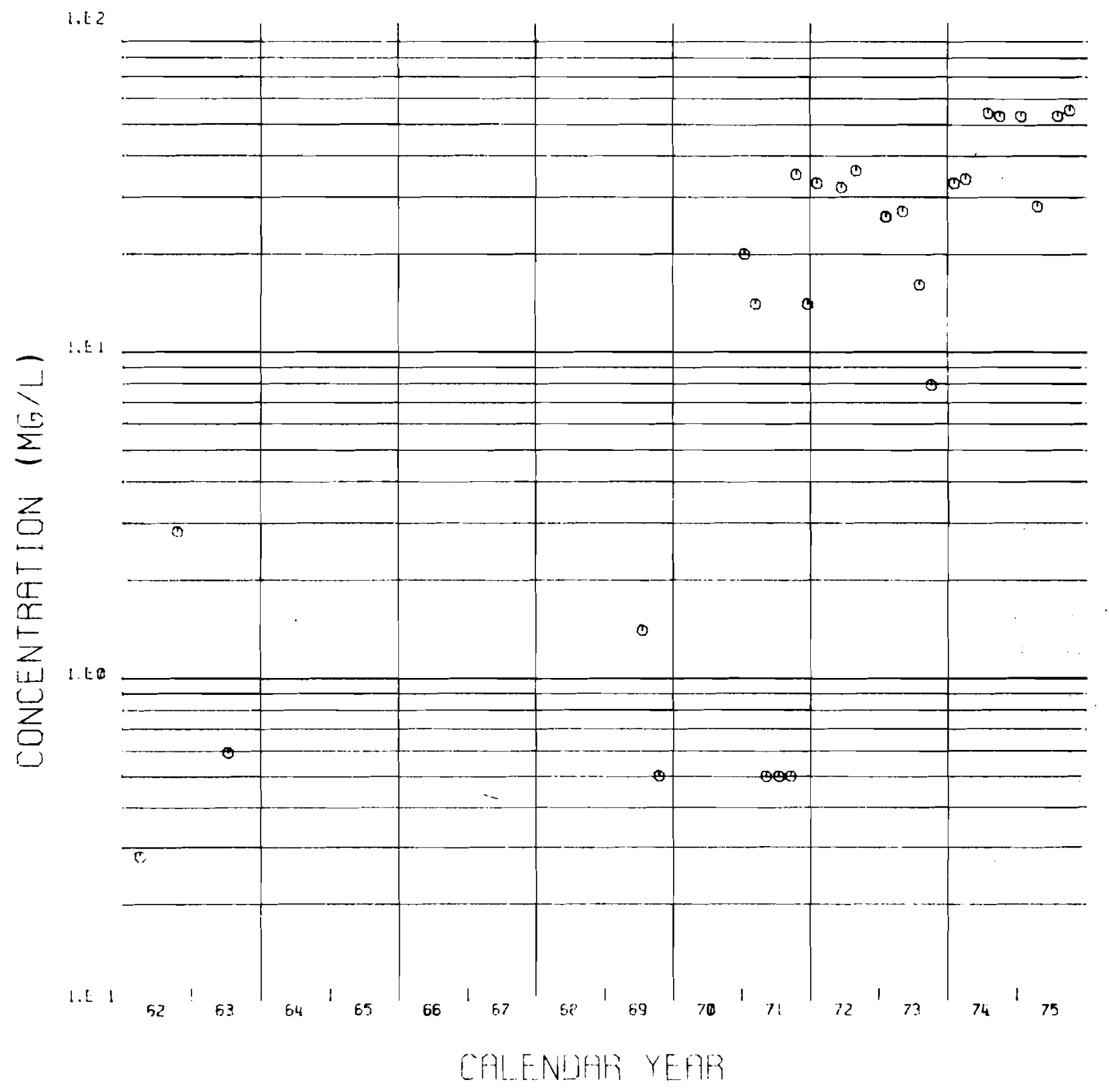

FIGURE 10. We11 699-27-8 Concentration History (Nitrate) 


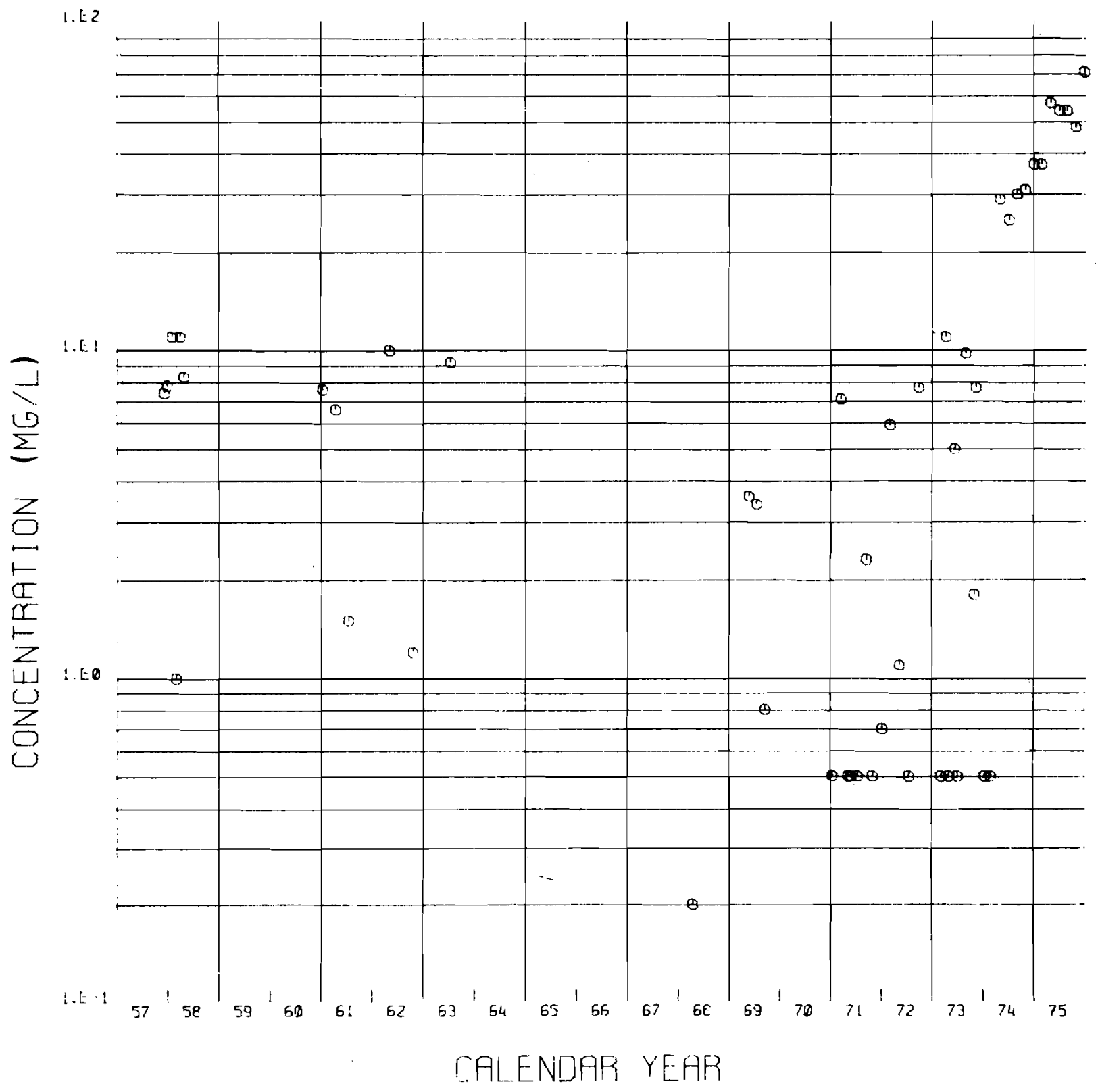

FIGURE 11. We11 699-17-5 Concentration History (Nitrate) 


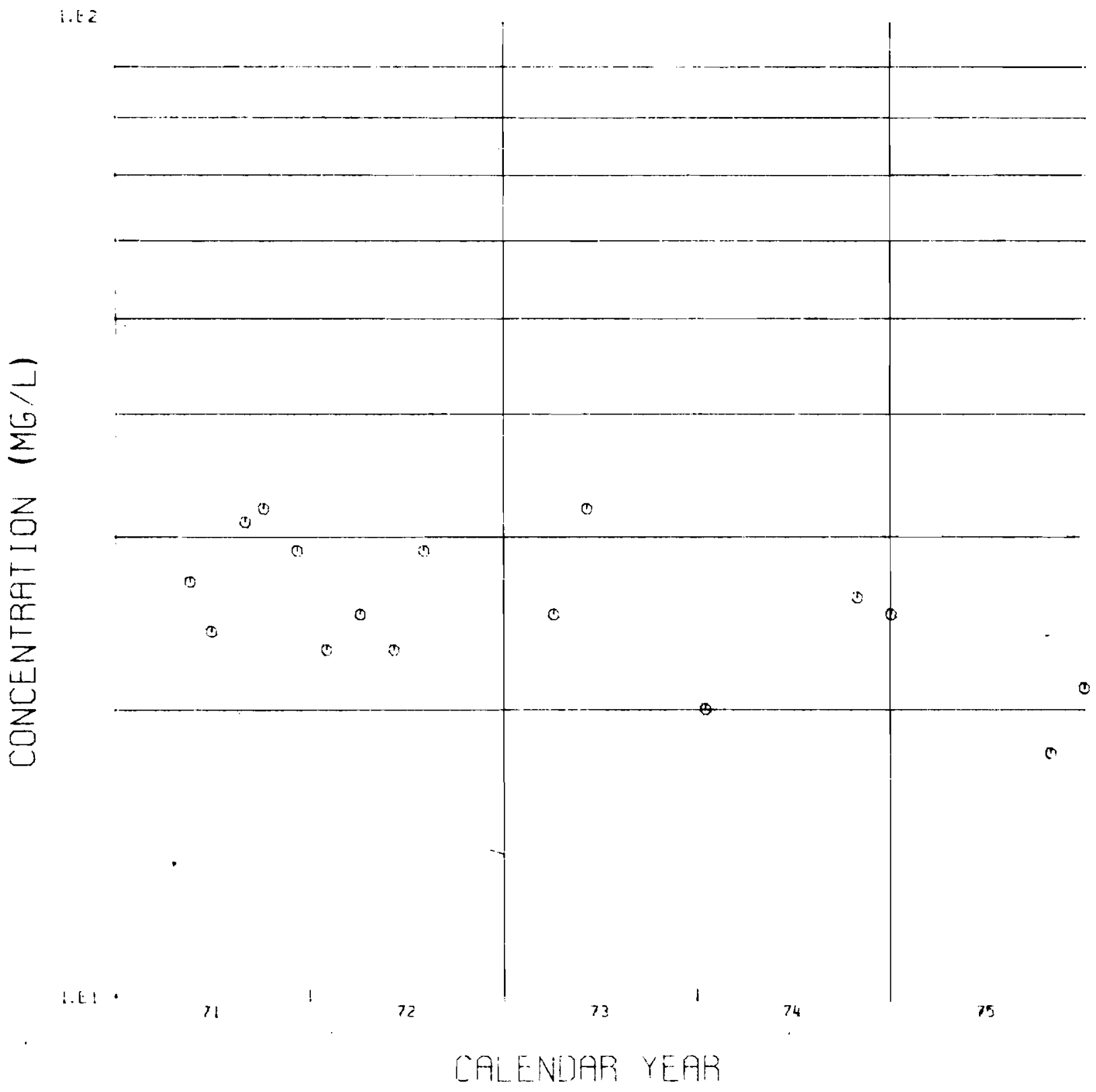

FIGURE 12. Wel1 699-8-25 Concentration History (Nitrate) 
TABLE 3. Iodine-129 Analyses from Selected Deep Wells on the Hanford Site, June 1975

\begin{tabular}{|c|c|c|c|}
\hline \multirow{2}{*}{$\frac{\text { We11 Number }}{699-31-31}$} & \multirow{2}{*}{$\begin{array}{l}\text { Sampling Depth } \\
\text { (ft blw LSD) } \\
127\end{array}$} & \multicolumn{2}{|c|}{${ }^{129} \mathrm{I}(\mathrm{pCi} / \ell)$} \\
\hline & & 12 & \pm 0141 \\
\hline & $270-284$ & 3.3 & \pm 0.1 \\
\hline & $350-364$ & 4. & \pm 0.41 \\
\hline & $395-409$ & 0.65 & \pm 0.066 \\
\hline & $>600$ & 4.1 & \pm 0.11 \\
\hline \multirow[t]{4}{*}{$699-37-43$} & $287-301$ & 0.061 & \pm 0.0018 \\
\hline & $365-383$ & 0.021 & \pm 0.0006 \\
\hline & $415-433$ & 0.0073 & \pm 0.00027 \\
\hline & $465-483$ & 0.00013 & \pm 0.0000048 \\
\hline \multirow[t]{4}{*}{$699-28-40$} & $280-290$ & 0.00082 & \pm 0.000028 \\
\hline & $340-350$ & 0.0018 & \pm 0.000048 \\
\hline & $400-410$ & 0.00057 & \pm 0.000016 \\
\hline & $450-460$ & 0.00024 & \pm 0.0000076 \\
\hline
\end{tabular}

STATUS OF CONTAMINATION IN THE LOWER AQUIFER (CONFINED ZONES)

Analysis of ground water from wells tapping the lower or confined aquifer, sampled as part of the routine program, show no contamination attributable to Hanford operations. There are only a limited number of locations onsite where samples representative of the confined aquifer can be obtained. Samples from these wells, as shown in Table 4, show no contamination. A more comprehensive program to assess the status of the confined aquifer is initiated by ARHCO. 
TABLE 4. Comparative Analyses, Lower Versus Upper Aquifer

\begin{tabular}{|c|c|c|c|}
\hline Well Number & $\begin{array}{c}3_{H} \\
\langle p C i / \ell)\end{array}$ & $\begin{array}{c}\mathrm{NO}_{3} \\
(\mathrm{mg} / \mathrm{l}) \\
\end{array}$ & $\begin{array}{c}\mathrm{Bt}_{\mathrm{t}} \\
(\mathrm{pC} \dot{\mathrm{i}} / \mathrm{l})\end{array}$ \\
\hline 699-S11-E12AP & $<825^{\star}$ & 8.5 & \\
\hline S11-E12A & $<1000^{\star}$ & 12 & \\
\hline $14-E 6 P$ & $<670^{\star}$ & $<0.5^{\star}$ & \\
\hline $14-E 6 S$ & $<950^{\star}$ & $<0.5^{\star}$ & \\
\hline $36-46 P$ & $<630^{\star}$ & $<0.5^{\star}$ & $<75^{\star}$ \\
\hline $36-46 Q$ & $<915^{\star}$ & $<0.5^{\star}$ & $<75^{\star}$ \\
\hline
\end{tabular}

*Less than detection limit

\section{THERMAL CONTAMINATION}

Mapping the thermal contamination of the unconfined ground water is another tool that can be used to assess the effects of plant operations. The thermal contamination of the ground water is of interest because the permeability of the sediments can be affected by an increase or decrease in fluid temperature.

Figure 13, in the rear pocket, shows the distribution of ground-water temperatures measured in November and December of 1975 . The temperature ranges shown are the result of: 1) natural temperature of the unconfined aquifer, about $15^{\circ} \mathrm{C}$ for the Hanford area; 2) changes due to natural phenomena such as bank storage near the Columbia River and discharge of groundwater from the warmer confined aquifers into the unconfined system; and 3) superimposed temperature gradients due to onsite operations.

The thermal plumes due to onsite operations are similar in shape and extent to the radionuclide plumes. Strikingly evident though, are the shut-down reactor areas where large quantities of hot water exit from ground disposal and retention basic leakage. Ground-water temperatures in the vicinity of the 100-B Area exceed $40^{\circ} \mathrm{C}$. 
The discharge of thermally contaminated ground water to the Cclumbia River has no noticeable effect on river temperatures. This is because only minor amounts of heated water reach the river.

\section{QUALITY CONTROL}

A program to institute quality control measures was initiated during 1974. This program reaches to a 11 phases of the Ground-Water Monitoring Program. An extensive effort to insure that samples are representative of the aquifer system beneath the site includes: 1) well maintenance: 2) visual and geophysical inspection; and 3) installation of sampling pumps. In addition, a program of blind and duplicate samples to the BNW Technical Analysis Laboratory was initiated. Outside analysis of ground-water samples by the U.S. Geological Survey was continued. These programs have shown that data received as part of the routine monitoring program are within the set 1 imits of accuracy. Data derived from external analyses are shown in Appendixes C and D. Table 5 compares analyses of the U.S. Geological Survey and Battelle Laboratories. The comparison of results obtained from different laboratories (Table 5) shows both the strengths and weaknesses inherent in the program. Radiological analyses compare favorably over the entire spectrum of concentrations while the nonradiological $\mathrm{NO}_{3}^{-}$analyses do not. The weakness is being strengthened by changing the analytical techniques used, bringing them into line with accepted EPA procedures. 
TABLE 5 Comparison of Analytical Results Between Laboratories

\begin{tabular}{|c|c|c|c|c|c|c|}
\hline \multirow[b]{2}{*}{ We11 Number } & \multicolumn{2}{|c|}{$\mathrm{NO}_{3}(\mathrm{mg} / \mathrm{l})$} & \multicolumn{2}{|c|}{$3_{H}^{1}(p C i / m l)$} & \multicolumn{2}{|c|}{$\beta_{t}^{2}(p C i / m 1)$} \\
\hline & USGS & BNW & USGS & BNW & USGS & BNW \\
\hline 699-S11-E12A & 22 & $\sim 0.5$ & 0.48 & 0.5 & & \\
\hline$S 6-E 4 D$ & & & 2.7 & 1.5 & & \\
\hline $2-3$ & 22 & 18 & 46 & 62 & & \\
\hline $9-\mathrm{E} 2$ & 1.2 & 0.5 & & & & \\
\hline $15-15 B$ & 16 & 13 & 0.48 & 0.5 & 0.011 & 0.08 \\
\hline $8-32$ & 9.3 & 0.5 & 0.48 & 1. & & \\
\hline $17-5$ & 53 & 37 & 0.48 & 0.53 & & \\
\hline $27-8$ & 58 & 53 & 880 & 880 & 0.25 & 0.2 \\
\hline $32-22$ & 75 & 67 & 1500 & 1600 & 0.24 & 0.26 \\
\hline $40-1$ & 24 & 0.6 & 84 & 0.75 & & \\
\hline $41-23$ & 53 & 50 & 890 & 880 & .074 & .075 \\
\hline $42-12$ & 28 & 30 & 230 & 280 & .057 & .080 \\
\hline $49-55$ & 12 & 0.5 & 0.48 & 0.5 & .015 & .075 \\
\hline $49-79$ & $44^{\prime}$ & 34 & 0.48 & 0.8 & & \\
\hline $50-42$ & 3.1 & 0.5 & 0.48 & 6.5 & & \\
\hline $69-38$ & & & 0.48 & 0.5 & & \\
\hline HAN 19 & 4.2 & 3.5 & 0.48 & 1 & & \\
\hline $\begin{array}{ll}\text { (1) } & \text { Minimum } \\
\text { (2) } & \text { Gross bet } \\
\text { USGS ana } \\
\text { lated as } \\
& 0.08 \mathrm{pC}\end{array}$ & $\begin{array}{l}\text { sable } \\
\text { calc } \\
\text { are } \\
\text { ar. B } \\
\text { t. }\end{array}$ & $\begin{array}{l}\text { H for } \\
\text { lated } \\
\text { alcula } \\
\text { ttelle }\end{array}$ & $\begin{array}{l}\text { laborator } \\
\text { erently } \\
\text { as } 137 \mathrm{Cs} \\
\text { oratories }\end{array}$ & $\begin{array}{l}\text { es is } 0.4 \\
\text { the two } \\
\text { nd the } B N \\
\text { have a mi }\end{array}$ & $\begin{array}{l}\text { nd } 1.0 \\
\text { oratori } \\
\text { nalyses } \\
\text { um coun }\end{array}$ & $\begin{array}{l}\text { espectively. } \\
\text { are calcu- } \\
\text { ate of } \\
\text { rate }\end{array}$ \\
\hline
\end{tabular}


RADIOLOGICAL IMPACT

Ground-water transport of contaminants on the Hanford site represents a potential pathway of exposure via water obtained from either 1) wells which tap the unconfined aquifer, or 2) the Columbia River into which the unconfined aquifer discharges. The following discussion examines these two potential pathways.

GROUND WATER

Presently the contaminant plumes are restricted to the Hanford site as shown in Figures 2, 3, and 4. As the plumes expand, concentrations within them will gradually decrease through additional dilution, adsorbtion for most of the constituents and in the case of radionuclides, decay.

Drinking water is obtained from the unconfined ground water at the FFTF and WPPSS sites. Monitoring is carried on at regular intervals at these sites. Onty the ${ }^{3} \mathrm{H}$ and $\mathrm{NO}_{3}^{-}$plumes extend to these locations. At the FFTF site, ${ }^{3} \mathrm{H}$ levels were $0.3 \%$ of the concentration guide and the $\mathrm{NO}_{3}$ levels averaged $16 \%{ }^{(5)}$ of the DWS. At the WPPSS site, ${ }^{3} \mathrm{H}$ levels averaged $3 \%$ of $\mathrm{CG}$ and $\mathrm{NO}_{3}^{-}$ concentrations averaged $10 \%$ of DWS.

\section{COLUMBIA RIVER}

The unconfined aquifer empties into the Columbia along the Hanford reach with a calculated flow of less than 100 cubic feet per second (cfs). (These flows were based upon operation of the Hanford ground-water models.) Dissolved materials resulting from 200 Area Waste Disposal Operations are transported by this flow. Superimposed upon this flow is seepage from the 1301-N trench. The average flow of the Columbia River is 130,000 cfs. The combined effects of: 1) small flow of ground water entering the river; 2) low concentrations of possible contaminants; 3) release of much larger quantities of similar materials from the 1301-N trench; and 4) the large dilution factor of the Columbia River have precluded the detection of any impact of any contaminant transported by the ground water. Extensive 
sampling of the Columbia River, above and below the Hanford reach, has shown no observable impact from known releases to the river due to seepage from the 1301-N trench during $1975{ }^{(6)}$

In summary, there has been no observable effect on the Columbia River by ground-water transported contaminants. All the concentrations observed to date are less than $10 \%$ of the most restrictive ERDA manual chapter guidelines. In fact, the values are less than concentrations of naturally occurring or worldwide fallout radioactivity in the Columbia River. (7) 


\section{REFERENCES}

1. J. R. Raymond, et al., Environmental Monitoring Report on Radiological Status of the Groundwater Beneath the Hanford Site, January December 1974, BNWL-1970 Battelle, Pacific Northwest Laboratories Richland, WA, March 1976.

2. U.S. Energy Research and Development Administration, "Standards for Radiation Protection," Chapter 0524, (Appendix) Annex A, Table II, Column 2, April 1975.

3. Recommended Drinking Water Standards, U.S. Public Health Service, Washington, DC, 1962.

4. V. L. McGhan, D. A. Myers and D. W. Damschen, Hanford Wel1s, BNWL-1981 Battelle, Pacific Northwest Laboratories, Richland, WA, March 1976.

5. L. J. Maas, Chemical and Biological Pollution Surveillance of the Hanford Environs, July 1 - December 31, 1975, HEHF, Richland, WA, 1976.

6. D. R. Speer, J. J. Fix and P. J. Blumer, Environmental Surveillance at Hanford for $\mathrm{CY}-1975$, BNWL-1979, Battel1e, Pacific Northwest Laboratories, Richland, WA, April 1976.

7. J. J. Fix, A "Filter-Resin" Sampling Method for Measurement of Radioactivity in Columbia River Water, BNWL-SA-5630, Battelle, Pacific Northwest Laboratories, Richland, WA, 1975. 
APPENDIX A

GROSS BETA, TRITIUM \& NITRATE CONCENTRATIONS

IN THE GROUND WATER (UNCONFINED AQUIFER) 


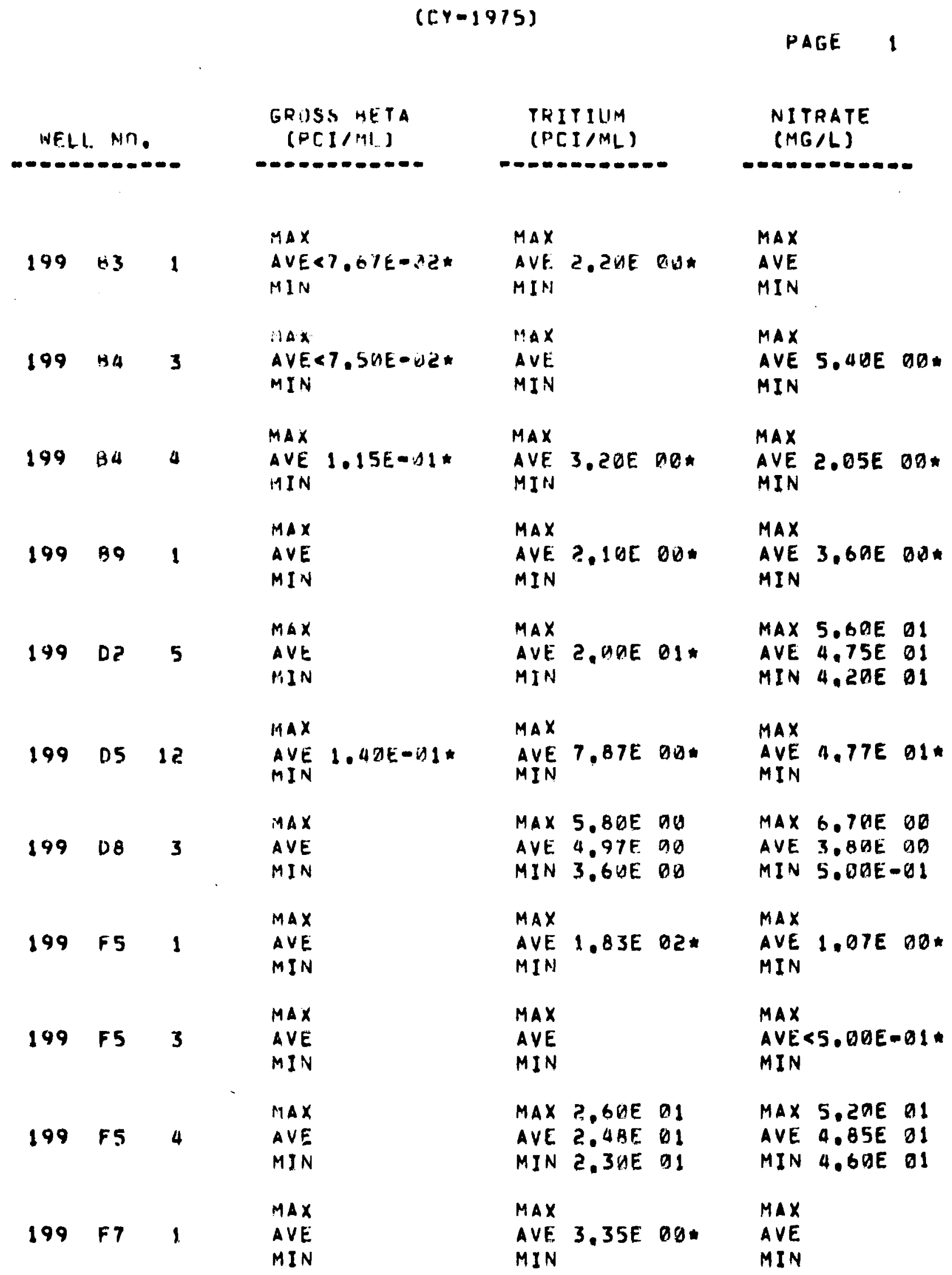


WELL NC.

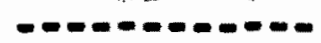

$199 F 8 \quad 2$

$199+33 \quad 1$

$199 \times 11$

$199 \times 19$

$199 \quad k \quad 20$

$199 \times 22$

$199 N \quad 15$

$299 E 13 \quad 1 ?$

$299 E 16$ ?

299 E17 5

$$
(C Y-1975)
$$

PAGE 2

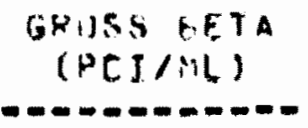

$M A X$

AVE

MIN

MAX

AVE

MIN

MAX

AVE

MIN

\section{MAX}

AVE

MIN

MAX

AVE

MIN

MAX

$\triangle V E<7.75 E-D 2 *$

$M I N$

MAX

AVE

MIN

MAX 3.36E-G1

AVE 2.34E-31

MIN 1.40E-OI

$M A X<8, \theta A E=\lambda 2$

AVE<1.92F-D2

$M I N<7.50 E-\omega 2$

MAX 9.DGE-D?

AVE 7.9?E- U.?

MIN 7.5 SU-ZIE

MAX 1.1ดE-01

AVE B.92E-D2

$M I N<7.50 E-A 2$

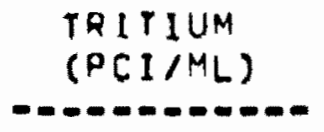

NITRATE

(MG/L)

MAX

AVE 1.97E U1*

MIN

MAX

AVF 2.10E QI*

MIN

MAX

AVE. 1, 35E OI*

MIN

MAX

AVE 3.52E 02*

MIN

MAX 7.60E OQ

AVE 6.58E 00

MIN $5.40 E$ OO

MAX $7.10 E$ OQ

AVE 6.25E DO

MIN $5.90 E 00$

MAX 4.3 OSE DO

AVE $2.90 E$ DO

MIN 2.10E OQ

MAX

AVE 3.47E 01*

MIN

MAX 4.6OE OI

AVE $1.15 E$ OI

MIN 5. AOE-DI

MAX

AVE

MIN

MAX

AVE

MIN
MAX

AVE 4.80E 01* MIN

MAX

AVE 4.80E 01 . MIN

MAX 4.0BE DI

AVE $2.90 E$ DI

$M I N$ 1.80E 0I

MAX 1.40E 01

AVE 7.03E DO

MIN 1.OQE OQ

MAX 3.50E 00

AVE 2.18E 90

MIN 1.60E 00

MAX 1.70E 09

AVE 1.35E 00

MIN $1.10 E$ OQ

MAX 6.ODE-OI

AVE $5.50 E-D 1$

MIN 5 , DAE-DI

MAX

AVE 1.23E O1*

MIN

MAX

AVE

MIN

MAX

AVE

MIN

MAX 1.5OE O2

AVE $1.05 E$ Q2

MIN $\angle 5, D O E$ OI 


$$
(C Y-1975)
$$

WELL NH.

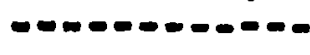

299 E17 8

$299 E 24 \quad 2$

299 E24 4

$299 E 24 \quad 9$

299 E25 B

$299 \quad 225 \quad 11$

$299 E 26 \quad 2$

$299 E 26 \quad 4$

$299 E 28 \quad 4$

299 E2B 5

299 E2B 7

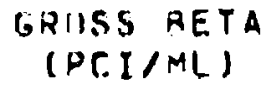

MAX

AVE 8.BDE-AZ*

MIN

MAX

AVE<8. DDE- 92 *

MIN

MAX

AVE 2.15E OU* MIN
TRITIUM

(PCI/ML)

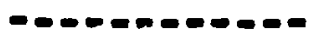

MAX

AVF

MIN

MAX 6.7 OAE 03

AVE 5.47E DS

MIN $4.2 D E$ OI

MAX

AVE 5.50E 02*

MIN

MAX

AVE

$M I N$

MAX 3.8DE 92

AVE 2.71F D2

MIN 2.IDE U?

MAX

AVE

MIN

MAX

AVE

MIN

MAX 4,DGE O2

AVE $3.63 E$ Q2

MIN 3,10E Q2

MAX

AVE

MIN

NITRATE

$(M G / L)$

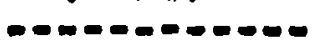

MAX

AVE

MIN

$\operatorname{MAX}$

AVE

MIN

MAX

AVE 1.60E 01*

MIN

MAX

AVE

MIN

MAX

AVE

MIN

$\operatorname{MaX}$

AVE

MIN

MAX

AVE

MIN

MAX

AVE

MIN

MAX

AVE

MIN

MAX MAX

AVE 4.05E DI*

MIN

AVE $8.35 E$ MQ MIN

MAX

$\operatorname{MAX}$

AVE

MIN 
APPENIIX A. GHOSS GETA, TRITIUM \& NITRATE CONCENTRATIONS
IN IME GRMUNU NATER (UNCONFINED AQUIFER)

$(C Y-1915)$

PAGE 4

WELL NO.

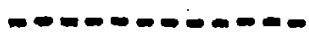

$299 \quad E 28 \quad 13$

$299 \quad 528 \quad 16$

$299 \quad E 33 \quad 119$

$299 \quad 533 \quad 14$

$299 \quad E 33 \quad 17$

$299 \quad E 33 \quad 25$

299 W6 1

299 w1ด 5

299 Wม1 7

299 W11 9

299 W11 12
GRUSS HFTA

(PCI/ML)

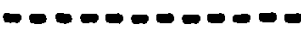

MAX $<4$, AHE - 12

AVE<T.75E- 12

MINE7,5It-A2

MAX 1. DOE-DI

AVE 8.17E-D2

MIN<7. 5BE.DZ

MAX

AVE 2. GOE-DI*

$M I$ iv

MAX

AVE B.DHE-DZ*

MIN

MAX

AVE 2.85E-D1*

MIN

MAX 1.4GE OU

AVE $8.65 E=101$

MIN 5.19E-DI

MAX

AVE

MIN

$M \Delta X$

AVE<7.50E-DDล

MIN

MAX

AVE 1.O2E DO*

MIN

MAX

AVE

MIN

MAX

AVE<7. 5HE-DZ*

MIN
TRITIUM

(PCI/ML)

-0-0.0-000-0

MAX

AVE

MIN

MAX

AVE

MIN

MAX

AVE $1.03 E$ OL.

MIN

MAX

AVE 9.4QE Q0"

MIN

$\operatorname{MAX}$

AVE

MIN

MAX 2.50E 02

AVE $1.90 E$ O?

MIN 1.60E Q?

MAX

AVE 2.95E 01*

MIN

MAX

AVE 2. 25E 01*

MIN

NITRATE

(MG/L)

- - - m-0.-0-0.0.

MAX

AVE

MIN

MAX

AVE

MIN

MAX

AVE 1.55E 01\%

MIN

MAX

AVE 1.55E Q1*

MIN

MAX

AVE

MIN

MAX 2.90E D2

AVE 2.37E O2

MIN 1.50E O2

MAX

AVE

MIN

MAX

AVE

$M I N$

MAX MAX

AVE 3.70E 02* AVE

MIN MIN

MAX MAX

AVE 5.40E DD* AVE 5.00E OD*

MIN

MIN

MAX MAX

AVE 1.30E Q2* AVE

MIN

MIN 
APPF, NOIX G. WHOSS HETA, THITIUN X NITRATE COMCENTRATIONS

IN IAT GIOUNO VIATER (UNCONF INES AGUIFEK)

$$
(C Y-1975)
$$

PAGE 5

WELL NO,

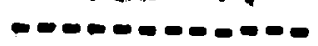

299 W11 17

$299 \times 15 \quad 2$

299 W15 7

$299 \times 18 \quad 5$

$299 \times 193$

299 W21 1

299 Wद2 1

299 W22 13

299 H22 $2 ?$

299 พ22 26

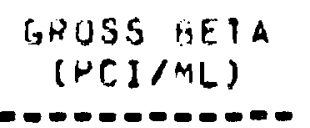

$M A X 1.56 E-111$

$A V E \quad 9.33 E-W 2$

$M I A:<7.5 A E-W 2$

$M \Delta X$

$A V E$

$M 1 N$

MAX

AVE

MIN

$\operatorname{MAX} 8.90 E-D 1$

AVE $4.97 \mathrm{E}-\triangle 1$

MIN 1. CWE-UI

$\operatorname{MAX} 1.90 E-D 1$

AVE 1.2ZE-OI

MIN 7 . SHE-OC

MAX

AVECT. SDE-DE*

MIN

$\operatorname{MAX}$

AVE 4.25E OO*

MIN

MAX 2.90E DI

AVE 2.3ZE U1

MIN 1.3GE UI

MAX

AVE 2,23E-D1*

MIN

MAX 4.10E-G1

AVE 3,32E- 11

MIN $2.4 D E-D I$

NAX $7.60 E$ OO

AVE 3.6OE WD

MIN 1. AAE LU
TRITIUM

(PCI/ML)

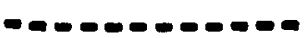

MAX

AVE

MIN

MAX

AVE $3,45 E-91$ 1*

MIN

MAX

AVE $<6,10 E=01 *$

MIN

MAX

AVE

MIN

MAX

AVE 8,80E DQ*

MIN

MAX

AVE Q.80E OI*

MIN

MAX

AVE 6.65E 03*

MIN

MAX

AVE

MIN

MAX 6. $40 E$ O3

AVE $4.45 E$ OS

MIN 3, UDE D3

MAX

AVE 4.50E 02*

MIN

MAX 1.30E O4

AVE $7.52 E$ Q3

MIN 4.8DE 03
NITRATE

(MG/L)

MAX

AVE

MIN

MAX

AVE 1.15E 02*

MIN

MAX

AVE 1.50E 01*

MIN

MAX

AVE

MIN

MAX

AVE 1.20E 02"

MIN

MAX

AVE 1.25E DI*

MIN

MAX

AVE $8.75 E$ OI*

MIN

MAX

AVE

MIN

MAX 7.1OE D2

AVE 1.23E O2

MIN 4.40E OO

MAX

$\triangle V E<5,00 E-01 *$

MIN

MAX

AVE 1.20E 02*

MIN 
APPENDIX 2. M.QUSS BETA, THIIIUM R NITRATE CONCENTRATIONS IN IHE LIROUNO NATEK (INCUNF INED AQUIFER)

NELL NT.

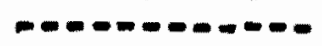

299 W23 4

39911

39912

39913

$399 \quad 14$

39938

$399 \quad 4 \quad 1$

$399 \quad 4 \quad 7$

$399 \quad 5 \quad 1$

$399 \quad 6 \quad 1$

$$
(C Y-19 / 5)
$$

PAGE 6

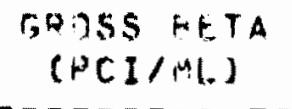

$-\infty-0--\infty--\infty-$

$M A X<0 . B A F=62$ $\triangle V E<7,15 E=22$

$M I N<1$. SSE $=32$

MAX 1.10E-D1

AVE 8. UDE-UI?

MIN $\angle 7.5 D E-D 2$

MAX 8. MOE $D 2$

AVE $7.75 E-02$

MINC $7.54 E-0 Z$

$M A X<B, A M E-12$

AVE<7.87E-D?

$M I N<7,50 E-D$ ?

$M A X<8,0 \cup E-$ DI 2

$\triangle V E<8,0 A E-02$

$M I N<B$. DUE- II

MAX $<8, \quad \triangle M E-D 2$

$A V E<7.58 E-D 2$

MIN $7.50 E-02$

MAX 6.3AE-DI

AVE 3.45E-D1

MIN 9.ODE-IZ

MAX $<\theta, D B E-D C$

AVE $<7.63 E-D 2$

$M I N<7.5 B E-\triangle 2$

$M A X<8, D U E-D 2$

$A \cup E<7,15 E-42$

$M I N<7,5 \cup E-U C$

MAX

AVE

MIN

MAX

AVE $<B, 0 O E-O 2$.

$M I N$

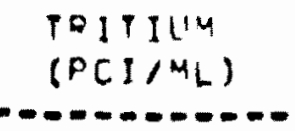

MAX 2.AJE T3

AVF $1.33 E$ И3

MIN 4.3 BIF 3

MAX

AVE

MIN

$\operatorname{MAX}$

AVE.

MIN

MAX

AVE

MIN

MAX

AVE

MIN

MAX

AVE

MIN

MAX

AVE

MIN

MAX

AVE

MIN

MAX

AVE

MIN

$\operatorname{MAX}$

AVE

MIN

MAX

AVE

MIN
NITRATE

(MG/)
MAX

AVE 1.9DE ด0.

MIN

MAX $1.60 E$ OI

AVE 1.DIE DI

MIN 3.90E OS

MAX $1.00 E$ OI

AVE 1.09E DI

MIN $7.9 B E$ OD

MAX 2.70E OI

AVE 1.51E O1

MIN $9.70 E$ DO

MAX $2.60 E$ DI

AVE I.01E OI

MIN T.9AE Da

MAX 3.3AE OI

AVE $1.13 E$ e I

पIN $9.92 E$ औ?

MAX

AVE $1.380 \mathrm{3l}$

MI

MAX l.bDE :1

ive l.ige il

MIT H.TE ?

ar 3.270 :

are l.ant it

al 1.1 it it:

wax 1.50?

lit 1.1? :

Ir 1. An

max 1.3it o:

are 1.0 a

ait $10:$ : 0 : 
WELL NO.

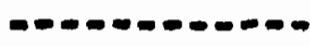

$699 \$ 31 \quad 1$

699. S3AE 15A

$699529 E 12$

$699 \$ 27 \quad E 14$

$699519 \quad E 13$

$699519 \quad 11$

995123

69951229

699 SIIEI $2 A$

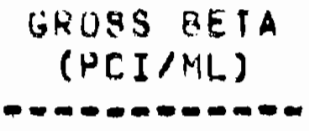

$$
\text { NAX 8.J9E-B2 }
$$

AVE $7.63 E-D 2$

NIN T. 5UE-DE

MAX

AVE

MIN

MAX

AVE

MIN

MAX

AVE

MIN

MAX

AVE

MIN

MAX

AVE

MIN

MAX

$\triangle V E \angle B, \triangle D E-D 2 *$

$M I N$

MAX

AVE

MIN

MAX

AVE

MIN

MAX

AYE

MIN

MAX

AVE

MIN
TRITIUM

(PCI/ML)

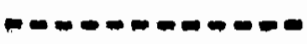

MAX

AVE

MIN

MAX

AVE

MIN

MAX 1.10E DO

AVE 7.55E.,DI

$M I N<4,8 D E=01$

MAX

AVE

MIN

MAX

AVE

MIN

MAX

AVE

MIN

MAX

AVE $8.0 B E-01$ *

MIN

MAX

AVE

MIN

MAX 1. BUE DO

AVE $1.08 E 00$

$M I N<5.60 E-01$

MAX

AVE

MIN

MAX 1.50E DO

AVE $8.72 E-91$

MIN $<4, B D E-0$ I

PAGE 7

NITRATE

(MG/L)

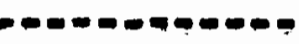

MAX 8.30E 00

AVE 7.80E 00

MIN 6.70E OQ

MAX $4.80 E 00$

AVE $3.92 E$ DQ

MIN 3. DOE OO

MAX

AVE 1.57E 00\%

MIN

MAX

AVE 9,50E-0!*

MIN

MAX

AVE I.DQE DI*

MIN

MAX

AVE 9.85E 00*

MIN

MAX 7.50E 00

AVE $4.63 E 00$

MIN 2.10E OO

MAX

AVE 6.60E.01*

MIN

MAX 6.20E OD

AVE $5.33 E$ DO

MIN Q.40E OO

MAX

AVE 5.30E-01*

MIN

MAX 1. BDE O1

AVE $1.24 E$ O1

$M I N<5.00 E-01$ 
APPENOIX A. GRTSS PETA, TEIIIUIA * NITRATE CONCENTRATIONS IN: IME GROUNU WAIEK (UNCONFINED AQUIFER)

WELL N!。

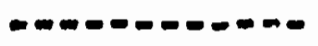

649 SB 19

699 S6 EAH

699 Sh E40

$699 \$ 3 \quad E 12$

$699 \mathrm{sa} \quad \mathrm{B}$

699118

69923

$699 \quad 2 \quad 33$

$699 \quad 345$

$699 \quad B \quad 17$

$699 \quad 8 \quad 25$

\section{$(C r-1975)$}

$P A G E \quad$ B

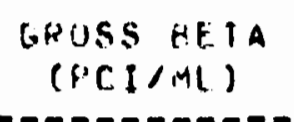

MAX

AVE

MI iv

MAX

AVE

MIN

MAX

AVE

MIN

MAX

AVE

MIN

MAX

AVE

MIN

MAX

$A \vee E$

$M I N$

MAX

AVE

MIN

$\operatorname{MAX}$

AVE

MIN

MAX

AVE

MIN

$\operatorname{MAX}$

AVE 8 . OดE-DZ*

MIN

$M A X<7,50 E=52$

$A V E<7.5 Q E-1 D 2$

MI:V $7,50 E-B 2$

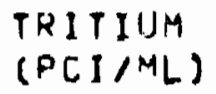

TRITIUM

(PCI/ML)

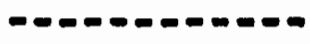

MAX $1.50 E$ OD

AVE $9.73 E-01$

$M I N<5,7 B E-D I$

MAX 5. ADE OQ

AVE $3.72 E$ OV

MIN I.BOE QO

MAX

AVE 2.94E OQ*

MIN

MAX

AVE<8,70E-01*

MIN

MAX 1.IUE DI

AVE B. $23 E$ OD

MIN 6.7DE DO

MAX

AVE 9.85E OI*

MIN

MAX 6.7ดE O2

AVE 2.12E D2

MIN 5.60E DI

MAX 1.RAE OO

AYE 1. D9E ดD

$M I N<4.8 \Delta E-D I$

MAX

AVE

MIN

$\operatorname{MAX}$

AVE 1.65E ด2*

MIN

MAX 1.7AE O3

AVE $5.48 E$ D2

MIN 1.6AE Q2
NITRATE

(MG/L)
MAX 2.4QE OO

AVE 1.96E DA

MIN I. OHE OD

MAX 1.2OE O1

AVE 1.04E 91

MIN $8.60 E$ DO

MAX 5.1AE OB

AVE $3.55 E$ Oด

MIN 7.DOE-DI

MAX 2. ADE O1

AVE $1.86 E$ OI

MIN $1.60 E$ OI

MAX

AVE

MIN

MAX 2.20E O1

AVE $2 . \triangle B E$ QI

MIN 2.UQE OL

MAX 2.10E O1

AVE 1.57E OI

MIN 3.00E OO

MAX

$A V E<5,0 Q E-01 *$ $M I N$

MAX

$\triangle V E$ 6.35E QD*

MIN

MAX

AVE 2.50E DI*

MIN

MAX

AVE 1.95E D1*

MIN 
HELL NN.

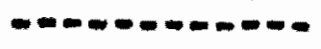

$699 \quad 32$

$499 \quad 9 \quad \mathrm{E} 2$

69919 E12

6991050

$699 \quad 13 \quad 1$

$699 \quad 13 \quad 14$

$699 \quad 13 \quad 18$

699 14 E6P

$69914 E 60$

699 ILEGR

69914 EbS

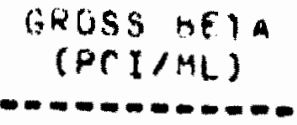

Mi X

$A V E$

HIN

$M A X$

AVE

MIN

$\operatorname{MAX}$

AVE

MIN

MAX

AVEQD.ODE- D2.

$M 1 N$

$\operatorname{MAX}$

AVE

MIN

MAX

AVE

MIN

$\operatorname{MAX}$

$A \cup E$

$M I N$

MAX

AVE

MIN

$M A X$

AVE

MIN

MAX

$A V E$

MIN

$\operatorname{MAX}$

AVE

MIN

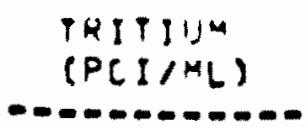

$\operatorname{MAX}$

AVE A.57E-01.

MIN

MAX

AVE $<9.65 E-111$.

MIN

MAX

AVE 7.40E-01*

MIN

MAX

AVE 9.5DE-D1*

MIN

MAX

AVE 6.77E O1*

MIN

MAX

AVE 2.42E O2*

MIN

MAX

AVE 2,7DE BI* MIN

MAX $1.10 E$ DO

AVE<6,7DE- 01

$M I N<4,8 \cup E=91$

MAX $<1.10 E \quad B O$

AVE\& $7.45 E-01$

$M I N<4.80 E-01$

MAX 1, 1UF UQ

AVE 7,65E-D1

$M I N<4, B D E-01$

MAX $<1.5 D E D O$

$A V E<9,52 E-01$

$M I N<4,89 E-01$
NITRATE

(4G/L)

MAX 5.6SE OA

AVE 2.67E OD

$M I N<5.00 E-01$

MAX 7.2DE-BI

AVE 5.55E-A1!

$M I N<5$. BUE - DI

MAX $<5.00 E-01$

$A V E<5.20 E-31$

$M I N<5 . O B E-D I$

MAX

AVE 4.90E DO.

MIN

MAX 1.20E OI

AVE 4.78E DO

MIN 2.10E OD

MAX

AVE 2.10E OD*

MIN

MAX

AVE 5.10E 00:

MIN

$M A X<5, D Q E-D I$

$A V E<5$. DOEE - DI

$M I N<5.00 E-B I$

$M A X<5, D D E-D 1$

$A V E<5, D A E-D 1$

$M I N<5.80 E-01$

$M A X<5, B A E-01$

AVE <5, DDE-01

$M I N<5,00 E=01$

$M A X<5, O Q E-01$

AVE $<5.00 E-01$

$M I N<5, O U E=D$ ! 
APPENDIX A. CHUSS HETA, TRIIIUM X NITRATE CONCENTRATIONS IN INE GROUNI) WATER (INCUNFINED AQUIFER)

WELL NO.

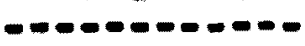

$699 \quad 15 \quad 155$

$699 \quad 15 \quad 26$

$699 \quad 17 \quad 5$

$699 \quad 19 \quad 43$

$69926<50$

69920 E12

$69920 \quad 20$

$699 \quad 20 \quad 39$

$69924 \quad 10$

$699 \quad 24 \quad 33$

$699 \quad 26 \quad 15$

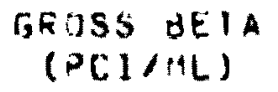

$-m--0-0-0=$

MAX

AVE $<B . W B E-\triangle 2 *$

MIN

MAX 1.2GE-B1

AVE $9.50 E-02$

$M I N<8$. WVE- $\triangle 2$

$\operatorname{MAX}$

AVE

MIN

MAX

AVE

MIN

$M A X$

AVE

MIN

MAX

AVE

MIN

MAX 1.1UE-D1

AVE $8.63 E-02$

$M I N<7,5 \Delta E-02$

MAX

AVE

$M I N$

$M A X$

AVE

MIN

$M A X<B, \operatorname{VOE}-D 2$

AVE $<7.15 E-D 2$

$M I N<7.5 B E-\triangle C 2$

MAX 1.6OE-O1

AVE $1.73 E-A 1$

MIN $1.60 E-31$
THIT IIIM

(PCI/ML)

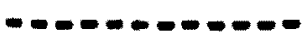

$M A X$

AVE I.2IE HO.

$M I N$

MAX

AVE 3.40E Q2ः

MIN

MAX 4. 4.DE AB

AVE 1.43E OD

$M I N<4.80 E-8 I$

MAX

AVE

MIN

MAX

AVE $9.35 E-P 1$.

MIN

MAX

AVE

MIN

MAX

AVE 5.35E ज2.

MIN

MAX $1.38 E-2$
AVE<9.13E- 11
MIN $7.13 E-71$
MAX
AVE $8.1 B E-B 1$
MIN

MAX

AVE 3, 20E R2०

MIN

$\operatorname{MAX}$

AVE 9.75E Q.2.

$M I N$

PAGE 10

NITRATE

(MG/L)

$---0---0-0$

MAX

AVE 7.97E OO*

MIN

MAX

AVE 2.45E 01:

MIN

MAX T.IUE OI

AVE 5.35E DI

MIN 3.70E OI

MAX 6.20E DO

AVE $5.65 E$ OD

MIN $5.10 E$ OD

$M A X<5.9 D E=01$

AVE $<5, B M E-B 1$

$M I N<5, B D E-B !$

MAX

AVE 5.59E-0!*

MIN

MAX

AVE Q.TAE OI.

HI

$4 x<5, \therefore=01$

$a x t<5, \therefore e-21$

a $145.2 x t=21$

mix 7.716

at $1 .: \cdots \quad \therefore$

$-1+4,3 t-1$

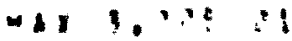

a. $2,40.8$

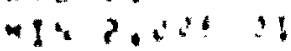

41

a.t $6.0 x$ l:

$\sim 14$ 
WELL NO.

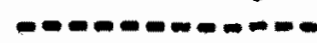

$699 \quad 28 \quad 40$

69931538

$699 \quad 31 \quad 65$

$699 \quad 32 \quad 22$

$699 \quad 32 \quad 62$

$699 \quad 32 \quad 79$

$699 \quad 32 \quad 12$

$\begin{array}{lll}699 & 32 & 77\end{array}$
$(C Y-1975)$

PAGE 11

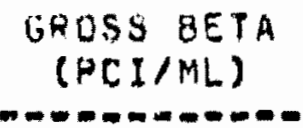

MAX

$A \vee E$

MIN

$\operatorname{MAX} 2.40 E-B 1$

AVE $2.0 Q E-D !$

MIN 1.70E-01

$M A X<B, O D E-D Z$

AVE $<7.75 E-92$

MIN T.SOEMOZ

$\max$

AVE

MIN

MAX

$A V E<7.50 E-02 *$

MIN

MAX

AVE

MIN

MAX

AVE 1.97E-01*

MIN

$\operatorname{MaX}$

AYE

MIN

$M \triangle X<B, U 0 E=02$

$A V E<7,15 E-D Z$

$M I N<7.5 D E=02$

MAX A.DUE-U2

AVE $7.63 E-02$

$M I N<7,50 E=D 2$

$M A X<B, D O E-\partial 2$

$A V E<7.7 M E-22$

$M I N<7.5 D E-D 2$
TRITIUM

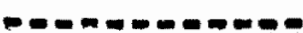

MAX

AVE

MIN

MAX

AVE 9, BDE DZ*

MIN

MAX

AVE $1.91 E$ 01*

MIN

MAX 2.20E OI

AVE 1.25E 90

MIN $8.40 E=01$

$M A X<1.40 E$ OO

$\triangle V E<9,10 E-01$

$M I N<4,80 E-0 I$

MAX

AVE 1.02E OD*

MIN

MAX

AVE 1.40E 03*

MIN

MAX

AVE 7.10E-01*

MIN

MAX 8.BDE O1

AVE $7,78 E$ O 1

MIN $6,70 E$ DI

MAX

AVE $8.45 E$ 01*

MIN

MAX 2.70E DO

AVE 1.14E OU

MIN T. ISE-OI
( $P C I / M L)$
NITRATE

(MG/L)
MAX

AVE 4.0OE OD.

MIN

MAX 5.50E O1

$\triangle V E$ 4.73E 1

MIN 2.80E OI

MAX $4.10 E 00$

AVE 1.55E DO

$M I N<5,00 E-01$

MAX 1.50E 00

AVE 1.15E OO

$M I N<5.0 D E-01$

MAX 1.DOE OI

AVE 6.25E OQ

MIN $3.70 E$ OO

MAX

AVE 1.32E Q1*

MIN

MAX

AVE 6.20E 01*

MIN

MAX

AVE 7.60E OD*

MIN

MAX

AVE 1,80E O1*

MIN

MAX 2.10E DO

AVE 7.67E-OI

$M I N<5,00 E m 01$

MAX 1.50E OI

AYE 1.17E O!

MIN 4. $40 E$ DO 
APPENOIX A. GQUSS AETA, TRITIU:A N NTRATE CONCENTRATIONS IN TME GROUNO WATER (UNCONFINEO AQUIFEK)

$$
(c r-1915)
$$

PAGE I?

WELL NM.

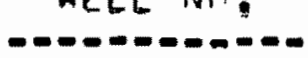

69934394

6993451

699359

$699 \quad 35 \quad 66$

6993579

6993578

$6993646 P$

$69936 \quad 400$

$69936 \quad 614$

$\begin{array}{lll}699 & 37 \quad 43\end{array}$

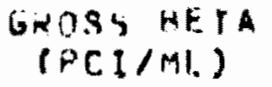

IIAX 1.20E-01

AVE $9,37 \mathrm{E}-0 \mathrm{Z}$

$M I N<B$. BDE- $A C$

MAX 1.8UE-01

AVE 1.5ME-OI

MIN I. 3UE-AI

MAX

AVE<7.5UE-102*

MIN

MAX $8, \triangle B E-62$

AVECT,75E-DE

$M I N<7.50 E-62$

MAX

AVE $<7.75 E-02 *$

MIN

MAX

AVE 1.3VE-Z1:

MIN

HAX $X B, B \cap E-B C$

AVE< $7.87 \mathrm{E}=\mathrm{U}$ ?

MINST . SME- 92

\section{MAX}

AVE 7.5DE-DE*

MIN

HAX $<8, D Q E-J ?$

$\triangle V E<7.87 E-\square 2$

MIN<T. SGE- $x^{4} 2$

$\operatorname{MAX}$

AVE<8, DDE- U2*

MIN

MAX $<B$. UAE -12 $A V E<7,63 E-D C$ $M I N<7,5 D E=02$

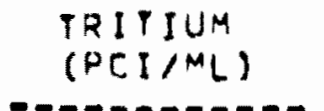

$\operatorname{MAX}$

AVE 1. TUE UI*

MIN

MAX 1.TAE OS

AVE 1.3AE 7.3

MIN 1.2AE UI

MAX

AVE 2.BOE OO*

MIN

MAX 3.1AE U1

AVE 2.58E 01

MIN 2.20E OI

MAX 3.30E Q?

AVE 1.19E DE

MIN 3,50E OI

MAX

AVE $9.20 E$ 03*

MIN

MAX 1.1DE DO

AVE B.7UE-01

MIN $7.70 E-01$

MAX

AVF 7. ODE-01* MIN

MAX 1.QDE OO

AVE 7.1 IDE-DI

MIN $\angle A, B U E=U 1$

MAX 3, 4AE OO

AVE. $1.48 E$ OQ

MIN 5.6UE-BI

MAX 2.6UE DD

AVE 1.29E DI

$M I N<6,4 B E-B 1$
NITUATE

(MTL)

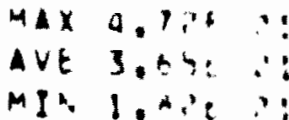

MAX 7,3:- :

AVE $5.811:$

MIN 3.SiL :

MAX 9,9.: :

AVE A. I. $\therefore$,

MIN $0.0 .1 \mathrm{i}$

MAX $2,3,9:$

AVE 1.3?! :

MIN 1.21: $\because$

MAX

AVE 5.61E.0:.

MIN

MAX

AVE 1.45E : :

MIN

MAX 6. TRE is

AVE $2,9,1 E$ :

MIN 1.3 .12 :

MAX

AVE $5.22 E \cdot I:-$

MIN

MAX $<5,70^{\prime} t \in:$ :

AVE $<5 . \therefore: *$

MIN<5, $\therefore$ IE $\therefore$ :

$\operatorname{MAX} 1.12: \therefore$

AVE 1. OOS $\therefore$

MIN $9.72 E \therefore$

MAX 5.3.: ?:

AVE $5.7^{\circ}-\therefore$ :

MINC5.:DE-I! 
APPFNIIX 1 . GUISS OFTA, TRIIIUY X NITRATE CONCENTRATITNS

IN IHE GNOUNU WATER (UNCONFINEU AOUIFFA)

WELL NO.

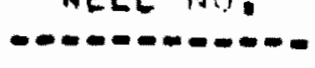

$699 \quad 37 \quad 824$

$699 \quad 38 \quad 19$

$699 \quad 39 \quad 19$

699401

$699 \quad 40 \quad 33$

6994962

6994123

$699 \quad 42 \quad 12$

$699 \quad 42 \quad 42$

$699 \quad 43 \quad 42$

$69943 \quad 89$

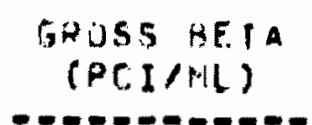

MAX

$A V E$

MIN

$M A X 2 . \Delta A E-1 D I$

AVE 2. $30 E-01$

$M I N 1.906-19$

$\operatorname{MAX}$

AVE

MIN

MAX

AVE

MIN

MAX

AVE

MIN

MAX

AVE

MIN

MAX

AVE $<7,67 E-1 D 2 *$

MIN

MAX

AVE

MIN

MAX

AVE

MIN

MAX

AVE

MIN

MAX

$A V E$

YIN

$$
(C Y-1975)
$$

PAGE 13
TRITIUM

(PCI/ML)

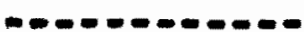

MAX 1.5DE DO

AVE $9.55 E-01$

MIN C6. GDE-UI

MAX 5.4DE OI

AVE $4.2 A E$ D!

MIN 3. DOE DI

MAX 1. $40 E$ DO

AVE $1.18 E .00$

MIN<1,0DE DO

MAX 7.BAE OI

AVE $6.96 E$ OI

MIN 6.40E OI

MAX 1.2DE DO

AVE 1.03E DO

MIN<7, DUE-DI

$\operatorname{MAX} 3.40 E$ OI

AVE 1.12E OI

MIN 1.7DE OO

MAX

AVE B.QUE D2*

MIN

MAX

AVE 2.70E 02*

MIN

MAX

AVE $7.20 E$ BO*

MIN

MAX

AVE 5.30E D2*

MIN

MAX

AVE $1.51 E 00$. MIN
NITHATE

(MG/L)
MAX 6.20E क1

AVE 5.23E DI

MIN 4.50E QI

MAX 2.70E A2

AVE 2.54E D2

MIN 2.25E D己

MAX $1.50 E$ OD

AVE 1.2OE OA

MIN T.DOE-DI

MAX

AVE

MIN

MAX

AVE 7.00E-01*

MIN

MAX

AVE 1.27E OI*

MIN

MAX

AVE 4.70E O1*

MIN

MAX 7.10E DI

AVE 3,45E DI

MIN 2.2UE OI

MAX

AVE 1.55E 00*

MIN

MAX

AVE

MIN

MAX 4.0OE OI

AVE $3.58 E$ Q1

MIN 3.20E OI 
APPENDIX A, GRUSS BETA, TEITIUM \& NITRATE CONCENTRATIONS IN THE GROUNO WATER (UHCONFINED ADUIFER)

$(C Y-1975)$

PAGE 14

NELL NO.

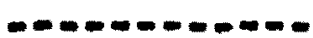

$69904 \quad 64$

$699 \quad 45 \quad 42$

$699 \quad 45 \quad 59$

$699 \quad 46 \quad 21$

$699 \quad 47 \quad 351$

$699 \quad 47 \quad 46$

$699 \quad 47 \quad 60$

6994871

$699 \quad 49 \quad 55$

$699 \quad 49 \quad 57$

$699 \quad 49 \quad 79$

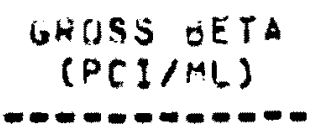

MAX

AVE

MIN

MAX

AVE

MIN

MAX

AVE

MIN

$M A X<B, D B E=\triangle Z$

$\triangle V E<7.87 E-\triangle 2$

MIN T. 5UE-D2

MAX

AVE

MIN

MAX

AVE

MIN

MAX

AVE

MIN

$\operatorname{MAX}$

AVE

MIN

$M A X$

AVE<7.50E-02*

MIN

MAX

AVE 1.53E OU*

MIN

$M A X$

AVE

MIN
THITIUM

(PCI/ML)

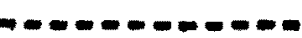

$M A X<1,24 E$ GM

$\triangle V E<8,435-21$

MIN $6.9 D E-\triangle 1$

MAX

AVE 6.35E O2*

MIN

MAX 3.3AE OI

AVE $8.99 E$ OD

$M I N<7,965-01$

MAX 6.7ดE OO

AVE 4.73E OB

MIN 3,30E DO

MAX 6.10F O.

AVE ?.25E OA

$M I N<7,00 E-11$

$M A X<1.20 E$ DJ

AVE<7,8BE-DI

$M I N<5,50 E-B 1$

MAX 8.10E-A1

AVE 6.92E-DI

$M I N<5, D D E-0 I$

MAX 1.20E DO

AVE 7,50E-01

$M I N \times 4,8 D E=01$

MAX $<1,23 E$ OB

AVE<7.86E- 111

MIN 5,DQE-OI

MAX 3,8UE D2

AVE $2,68 E$ D?

MIN 4. MQE-A2

MAX

AVEC L. ADE OD* $M I N$
NITRATE

(MG/L)

MAX
MVE $1.15 E$ JI.

MAX

AVE $<5, D O E-01:$

MIN

$M A X$

AVE 3.13E 21.

MIV

MAX 6.TOE AJ

AVE 5.9BE a2

MIN $5.22 E$ OO

MAX

AVE

MIN

$M A X$

AVE I.OZE EI

MIV

$\operatorname{Max}$

AVE $1.32 E$. 10

AIS

Mx

ME 1.11:-i!:

IV

$4 A \times 9, \therefore C$

are to*t is

una $4, ?-2$ !

WA

a.t : E T2

$\because:$

$-1$

a. 1.45 31.

ais 


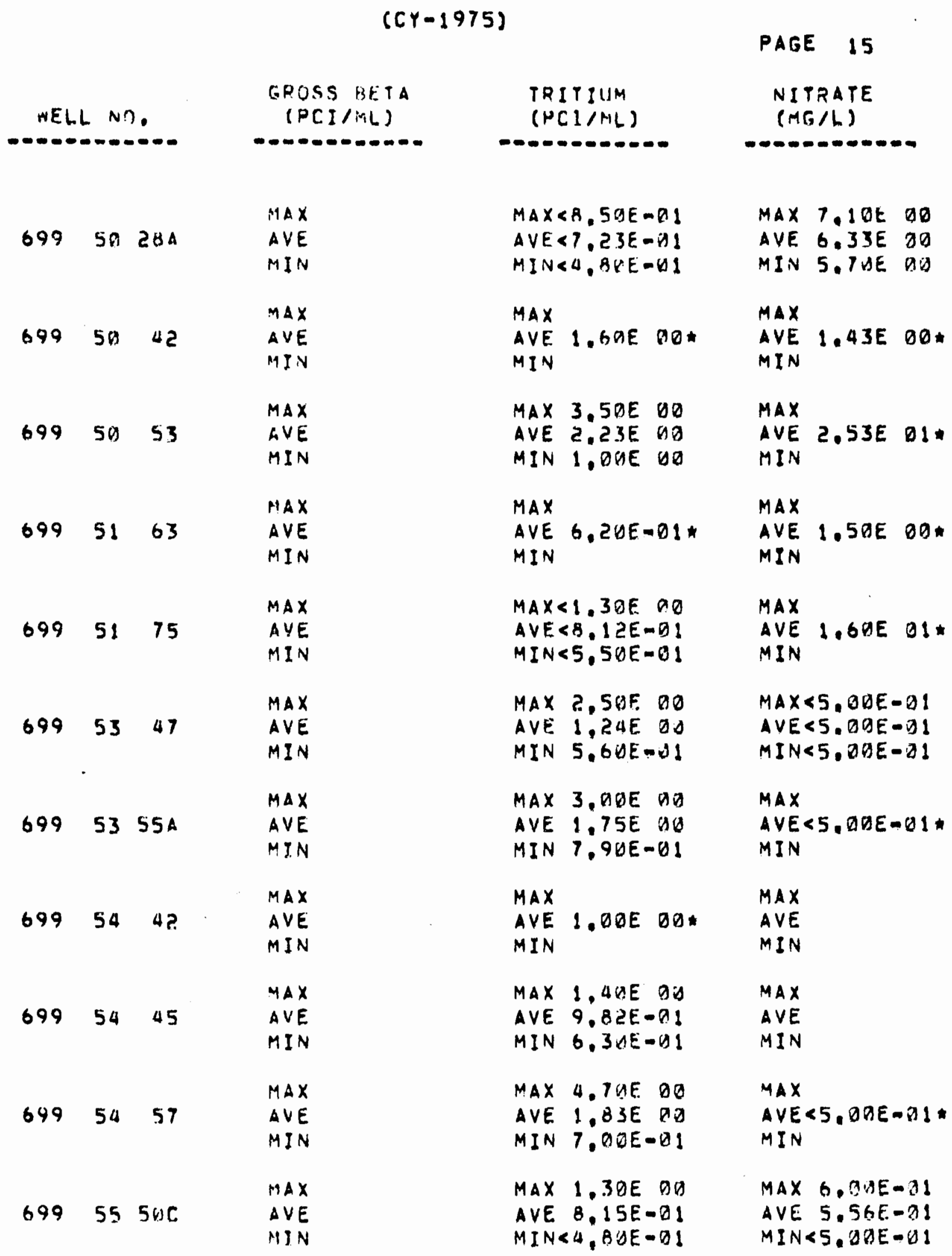


APPENUIX A, GRISS GETA, TRITIUM X NITRATE CONCENTRATIUNS IN THE GKUINO HATER (WNCONFINED ADUIFER)

\begin{tabular}{|c|c|c|c|c|c|}
\hline & & & & $75)$ & PAGE I6 \\
\hline WEL & $-\mathrm{MC}$ & & $\begin{array}{l}\text { GHOSS AETA } \\
\text { (PCI/AIL) }\end{array}$ & $\begin{array}{l}\text { TKI TIUM } \\
\text { (PCI/PL) }\end{array}$ & $\begin{array}{l}\text { NITRATE } \\
\text { (MEIL) }\end{array}$ \\
\hline----- & $-\infty$ & $-\infty$ & $-----0-0-0-0-$ & $----\infty-0-0-0-$ & $n-\infty-\infty-\infty-\infty-\infty-\infty$ \\
\hline 699 & $\$ 5$ & 10 & $\begin{array}{l}\text { MAX } \\
\text { AVE } \\
\text { MIN }\end{array}$ & $\begin{array}{l}M A X \\
A V E \\
M I N\end{array}$ & $\begin{array}{l}\text { MAX } \\
\text { AVE<5. EAE-iI } \\
\text { MIN }\end{array}$ \\
\hline 699 & 55 & 76 & $\begin{array}{l}\text { MAX } \\
\text { AVE } \\
M I N\end{array}$ & $\begin{array}{l}\text { MAX } \\
\text { AVE. } \\
\text { MIN }\end{array}$ & $\begin{array}{l}\text { MAX } \\
\text { AVE }<5, Q U E-P I . \\
\text { MIN }\end{array}$ \\
\hline 699 & 57 & 83 & $\begin{array}{l}\text { MAX } \\
A V E \\
M I N\end{array}$ & $\begin{array}{l}\text { MAX } \\
\text { AVE } \\
\text { MIN }\end{array}$ & $\begin{array}{l}\text { MAX } \\
\text { AVE }<5,0 Q E-P 1 \\
\text { MIN }\end{array}$ \\
\hline 699 & 59 & 58 & $\begin{array}{l}\text { MAX } \\
\text { AVE } \\
\text { MIN }\end{array}$ & $\begin{array}{l}\text { MAX } 4.8 U E \text { ODO } \\
\text { AVE } 4.20 E \text { OO } \\
\text { MIN } 3.50 E \text { OD }\end{array}$ & $\begin{array}{l}\text { MAX } \\
\text { AVE } 6.23 E-210 \\
\text { MIN }\end{array}$ \\
\hline 699 & 59 & $8 \cup P$ & $\begin{array}{l}\text { MAX } \\
\text { AVE } \\
\text { MIN }\end{array}$ & $\begin{array}{l}\text { MAX } \\
\text { AVE } \\
\text { MIN }\end{array}$ & $\begin{array}{l}\text { MAX } \\
\text { AVE } 3.7 T E \text { : } \\
\text { MIN }\end{array}$ \\
\hline 699 & 60 & 57 & $\begin{array}{l}\text { MAX } \\
\text { AVE } \\
\text { MIN }\end{array}$ & 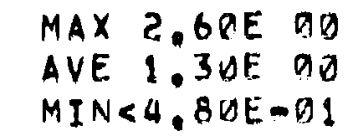 & $\begin{array}{l}\text { MAX } \\
\text { AVE }<5 . \text { DIE } P: 1 \\
\text { MIN }\end{array}$ \\
\hline 699 & 60 & 69 & $\begin{array}{l}\text { MAX } \\
A V E \\
M I N\end{array}$ & $\begin{array}{lll}\text { MAX } & 2.70 E & 00 \\
\text { AVE } & 2.28 E \\
\text { MIN } 1.70 E & 00\end{array}$ & $\begin{array}{l}\text { MAX } \\
\text { AVE } 5.67 E \cdot 2: \bullet \\
\text { MIN }\end{array}$ \\
\hline 699 & 61 & 62 & $\begin{array}{l}\text { MAX } \\
\text { AVE } \\
\text { MIN }\end{array}$ & $\begin{array}{l}\text { MAX } 2.30 E \\
\text { AVE } 1.83 E \\
\text { MIN } 1.30 E\end{array}$ & $\begin{array}{l}\text { MAX } \\
\text { AVE } 6.33 E \cdot:: \\
\text { MIN }\end{array}$ \\
\hline 699 & 61 & 66 & $\begin{array}{l}M A X \\
A \cup E . \\
M I N\end{array}$ & $\begin{array}{l}M A X<8.30 E-91 \\
A V E<6.47 E-D 1 \\
M I H<4.8 U E-01\end{array}$ & $\begin{array}{l}\text { MAX } \\
\text { AVE. } \\
\text { MIN }\end{array}$ \\
\hline 699 & 62 & 31 & $\begin{array}{l}\text { MAX } \\
\text { AYE } \\
\text { MIN }\end{array}$ & $\begin{array}{l}\text { MAX } \\
\text { AVE } \\
\text { MIN }\end{array}$ & $\begin{array}{l}\text { MAX } \\
\text { AVE<5, } \because: \cdots: 0 \\
\text { MIN }\end{array}$ \\
\hline 699 & 62 & $43 F$ & $\begin{array}{l}\text { MAX } \\
A \cup E \\
M I V\end{array}$ & $\begin{array}{l}\text { MAX } \\
\text { AVE } \\
\text { MIN }\end{array}$ & $\begin{array}{l}\operatorname{MAX} \\
\operatorname{AVE} 1, \therefore \cdots\end{array}$ \\
\hline
\end{tabular}

*--3 Vallies oh less, hu max dR min calculateo 


\section{$(C Y-1975)$}

PAGE 17

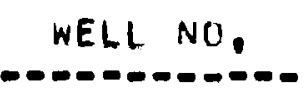

$699 \quad 63 \quad 58$

$69964 \quad 62$

$69965 \quad 50$

$699 \quad 65 \quad 59$

$69965 \quad 7 ?$

$699 \quad 65 \quad 83$

$699 \quad 66 \quad 23$

$699 \quad 66 \quad 39$

$699 \quad 66 \quad 58$

$69966 \quad 64$

$699 \quad 67 \quad 51$.

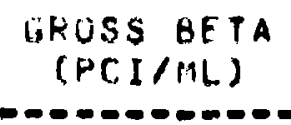

$\operatorname{MAX}$

AVE

MIN

$\operatorname{MAX}$

AVE

MIN

$M \Delta X$

AVE

MIN

$\operatorname{MAX}$

AVE

MIN

MAX

AVE

MIN

MAX

AVE

MIN

MAX

AVE

MIN

MAX

AVE

MIN

$\operatorname{MaX}$

AVE

MIN

MAX

$\triangle V E$

MIV

$M A X$

AVE

MI I

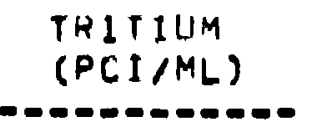

MAX 3.7UE DD

AVE 2.21E QQ

$M I N<7,3 D E-\theta !$

MAX 2.60E DO

AVE 1.76E OQ

MIN 9.6DE-DI

MAX

AVE Z.15E OD*

MIN

MAX

AVE 2.10E DO*

MIN

MAX 1.70E OO

AVE 1.40E 00

$M I N$ 1.20E $D O$

MAX 2, 90E DO

AVE 2.48E 00

MIN 2,30E $\triangle 0$

MAX

AVE

MIN

MAX

AVE

MIN

MAX 2. 9DE DO

AVE 2.16E DO

MIN 1.40E OO

MAX 1.2DE DO

AVE 9.60E-01

MIN 6.4DE-91

MAX

AVE 1.37E Q9.

MIN
NITRATE

(MG/L)
MAX

AVE 5.03E-0I

MIN

MAX

AVE 7.07E-01*

MIN

MAX

AVE 7.10E DO*

MIN

MAX

AVE <5. OOE-OI:

MIN

MAX

AVE 3.30E O0*

MIN

MAX

AVE 1.85E 00*

MIN

MAX

AVE Q5. OOE-BI*

MIN

MAX

AVE $<5, D D E-D I *$ MIN

MAX

AVE 5,73E-DI*

MIN

MAX

AVE 6.63E-01*

MIN

MAX

AVE 5.17E-OI:

MIN 
APPENDIX A. GROSS BETA, TRITIUY \& NITRATE CONCENIRATIONS

IN THE GNOUNO WATER (UNCONFINED AQUIFER)

$$
(C r-1975)
$$

PAGE 18

WELL NOL

$699 \quad 67 \quad 98$

69968105

$69969 \quad 38$

$69969 \quad 45$

$699706 B$

6997130

6997152

6997177

$699 \quad 72 \quad 73$

$699 \quad 72 \quad 48$

\section{GROSS BETA}

(PCI/ML)

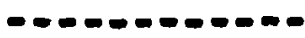

$M \Delta X$

AVE

MIIV

MAX

AVE

MIN

$\operatorname{MAX}$

AVE.

MIN

$\operatorname{MAX}$

AVE

MIN

MAX

AVE

$M I N$

MAX

AVE

MIN

$\operatorname{MAX}$

AVE

MIN

$M A X$

$\triangle V E$

MIN

$M \Delta X$

AVE

$M I N$

$\operatorname{MAX}$

AVE

MIN

$\operatorname{MAX}$

AVE

MIN
TRITIUM

(PCI/ML)

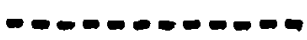

MAX

AVE 2,60E DOE

MIN

MAX

AVE $<9,20 E-B 1$ *

MIN

MAX
AVE 1,OOE OU*

MIN

MAX

AVE 1.05E 00*

MIN

MAX

AVE 3.25E 00*

MIN

MAX

AVE 1.12E OO*

MIN

MAX

AVE 1.05E DO* MIN

MAX

AVE 3.65E OO*

MIN

MAX 1.7DE 90

AVE 1.P6E OD

$M I N$ B. $40 E-D I$

MAX

AVE<1. DQSE OOH

MIN

MAX

AVE 1.00E 01*

MIN
NITRATE

(MG/L)

AX

AVE 1.30E OD*

MIN

MAX

AVE 2.60E OO०

MIN

MAX

AVE 1.00E DO*

MIN

MAX

AVEE 8,DQE-DI*

MIN

MAX

AVE<5, ADEE-PI* MIN

MAX

AVE 1.40E DO०

MIN

MAX

AVE 1.30E OO*

MIN

MAX

AVE 5.10E OO*

MIN

MAX

AVE 1,30E OQ*

MIN

MAX

AVE 1.60E O0. MIN

$\operatorname{MAX}$

AVE 1.40E DO० MIN 
APPENDIX A, WROSS BETA, TRITIUM R NITRATE CONCENTRATIONS IN THE LIROUNO WATER (UNCONFINEO AQUIFER)

$$
(C Y-1975)
$$

PAGE 19

WELL NO,

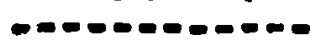

$699 \quad 72 \quad 92$

$69974 \quad 44$

$699 \quad 74 \quad 48$

$699 \quad 74 \quad 60$

$699 \quad 77 \quad 36$

$699 \quad 77 \quad 54$

$699 \quad 78 \quad 62$

$699 \quad 60 \quad 435$

6998158

$699 \quad 84 \quad 354$

$\begin{array}{lll}699 & 87 \quad 55\end{array}$

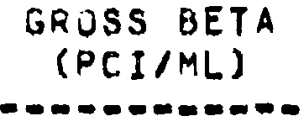

MAX

AVE

MIN

MAX

AVE

MIN

$\operatorname{MAX}$

AVE

MIN

MAX

AVE

MIN

MAX

AVE

MIN

MAX

AVE

MIN

MAX

AVE

MIN

MAX

AVE

MIN

MAX

AVE

MIN

MAX

A'VE

MIN

MAX

AVE

MIN
TRITIUM

(PCI/ML)

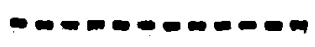

MAX

AVE 1.4DE 01*

MIN

$M A X<8,4 \Delta E-61$

$\triangle V E<5,75 E-01$

$M I N<4.80 E-01$

MAX 2.4DE DO

AVE $1.84 E$ DO

MIN 1.30E OO

MAX $<1.1$ DE DD

AYE<7.65E-01

MIN 5,DDE-DI

MAX 1.30E DO

AVE $8,65 E-0 !$

MIN $5,40 E=01$

MAX

$A V E<8,50 E-D 1$ 1*

MIN

MAX 1.10E DO

AVE $8,15 E-01$

MIN 5.7DE-DI

MAX

AVE 7.85E-01*

MIN

MAX 1.1OE OO

AVE $8.4 \square E-01$

MIN $5.00 E-01$

MAX

$A Y E<8.90 E-01 *$

MIN

MAX 1.DRE DZ

AVE $\$ .35 E$ DI

MIN 7.20E OI
NITRATE

(MG/L)

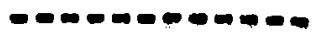

MAX

AVE 3.40E 00*

MIN

MAX

AVE \&5. OOEDDI*

MIN

MAX

AVE 3,60E 00*

MIN

MAX

AVE 7.00EMOl*

MIN

MAX

AVË 2.45E 02*

MIN

MAX

AVE 5.50E 00

MIN

MAX

AVE $4.30 E$ 00*

MIN

MAX

AVE 3.50E 00*

MIN

MAX

AVE 9.00E-OOL

MIN

MAX

AVE 4.70E DO*

MIN

MAX

AVE 9.95E. DO*

MIN 
APPENDIX A. TOLOSS HFTA, TRIIIUM \& NITRATE CONCENTRATIONS

IN THE GQOUNI) WATER (UNCUNFINEO AOUIFER)

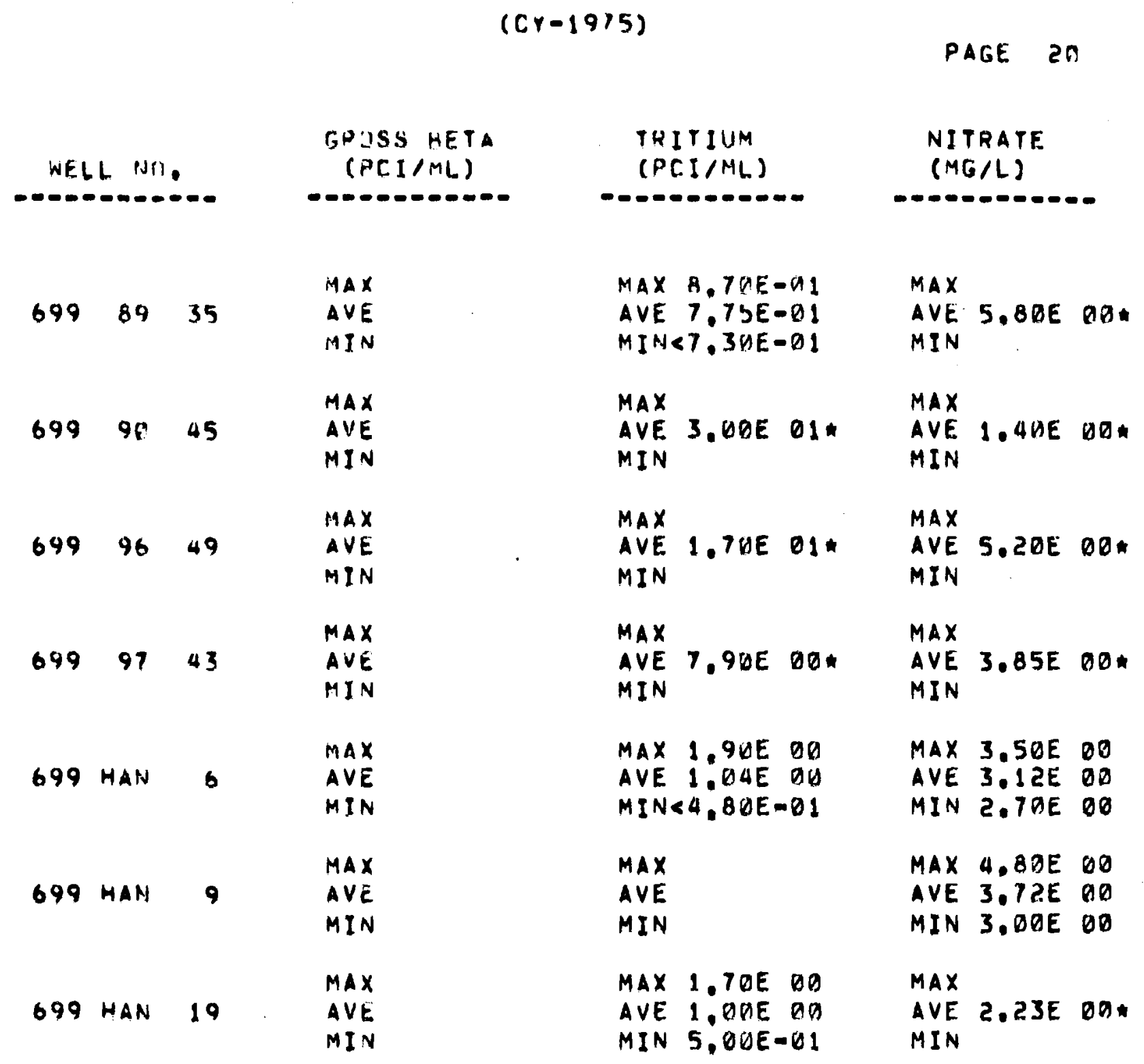


APPENDIX B

ROUTINE ANALYSES FOR MATERIALS OTHER THAN PRIMARY TRACERS 
APPENDIX B

ROUTINE ANALYSES FOR MATERIALS OTHER THAN PRIMARY TRACERS

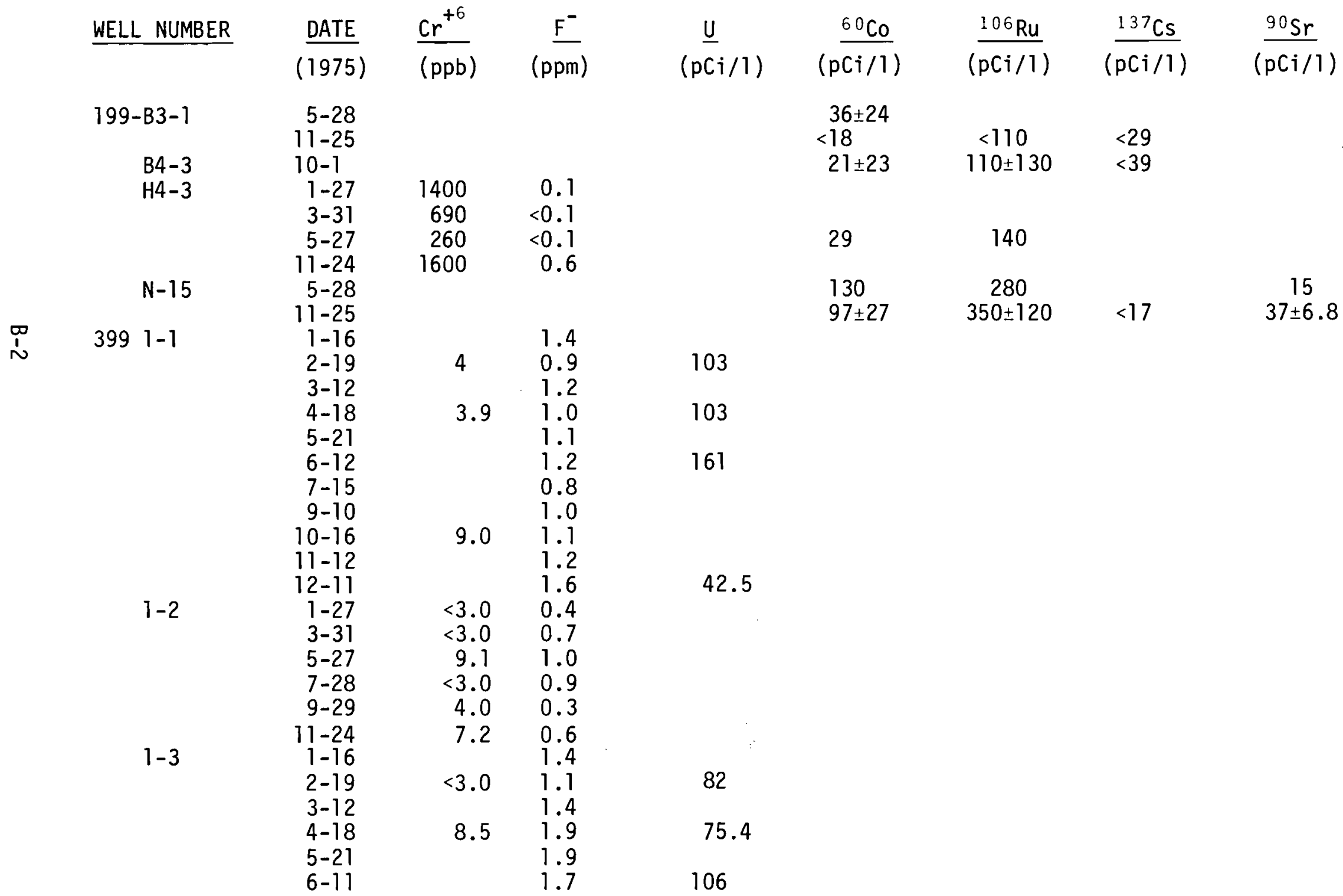




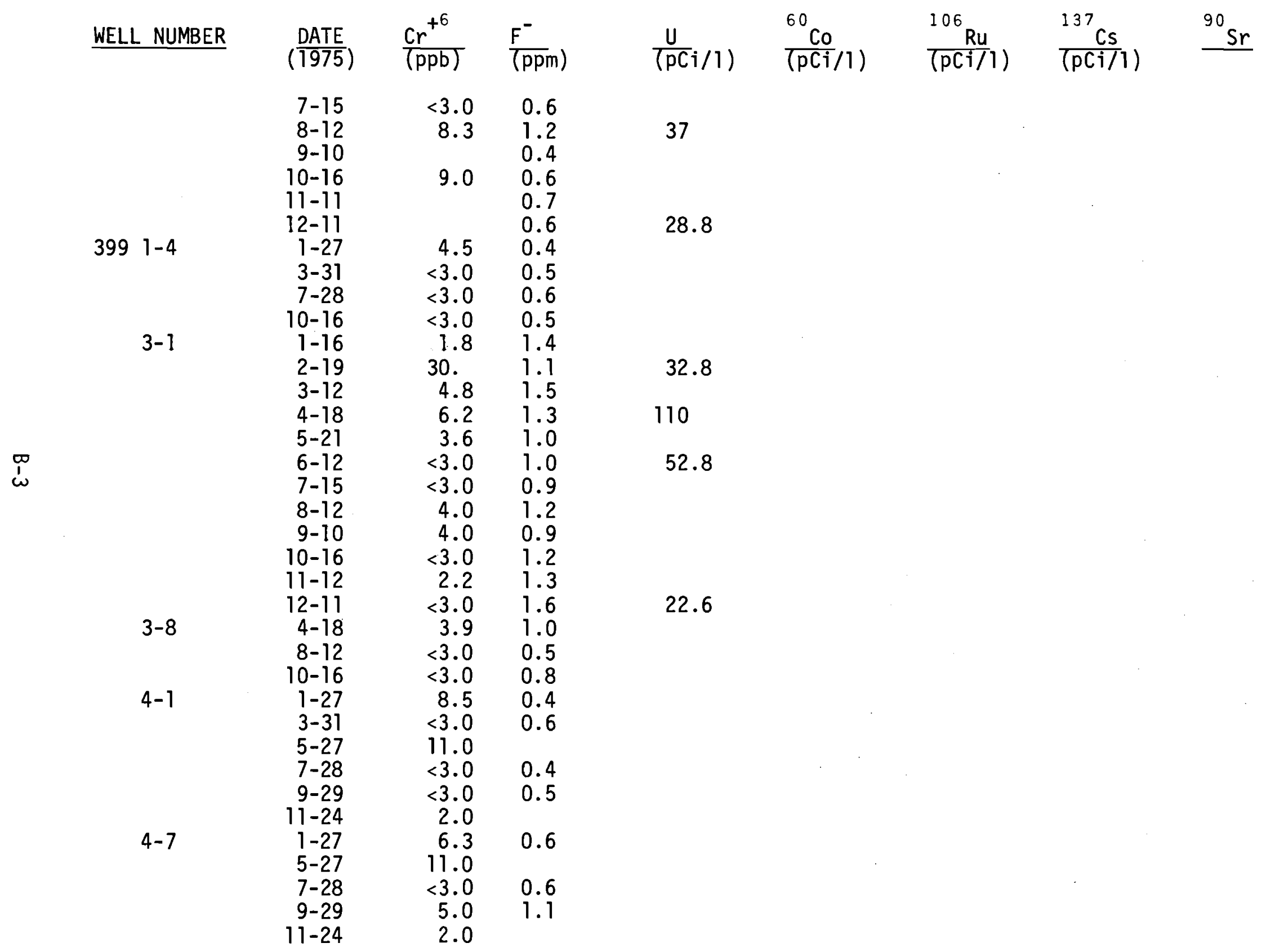




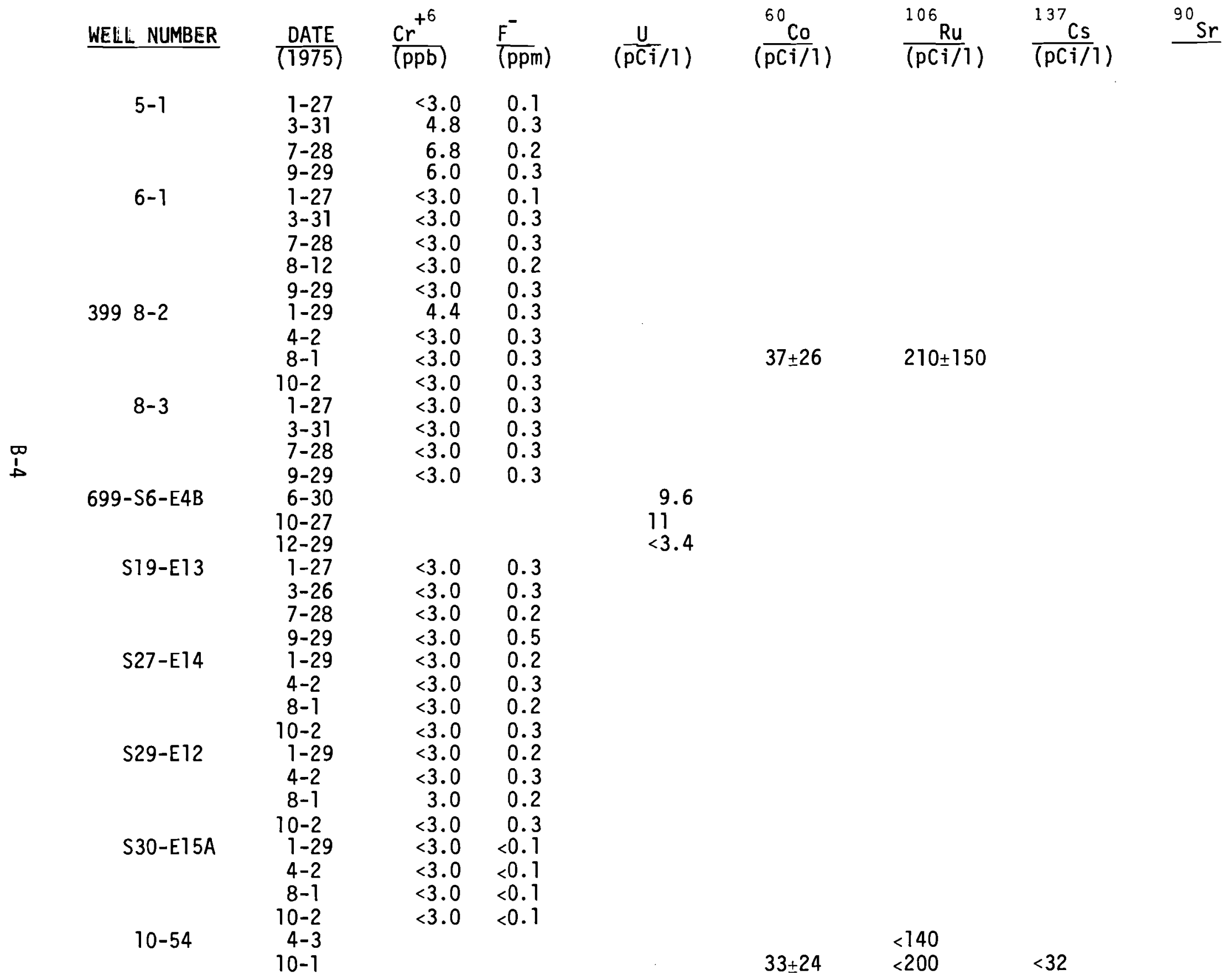




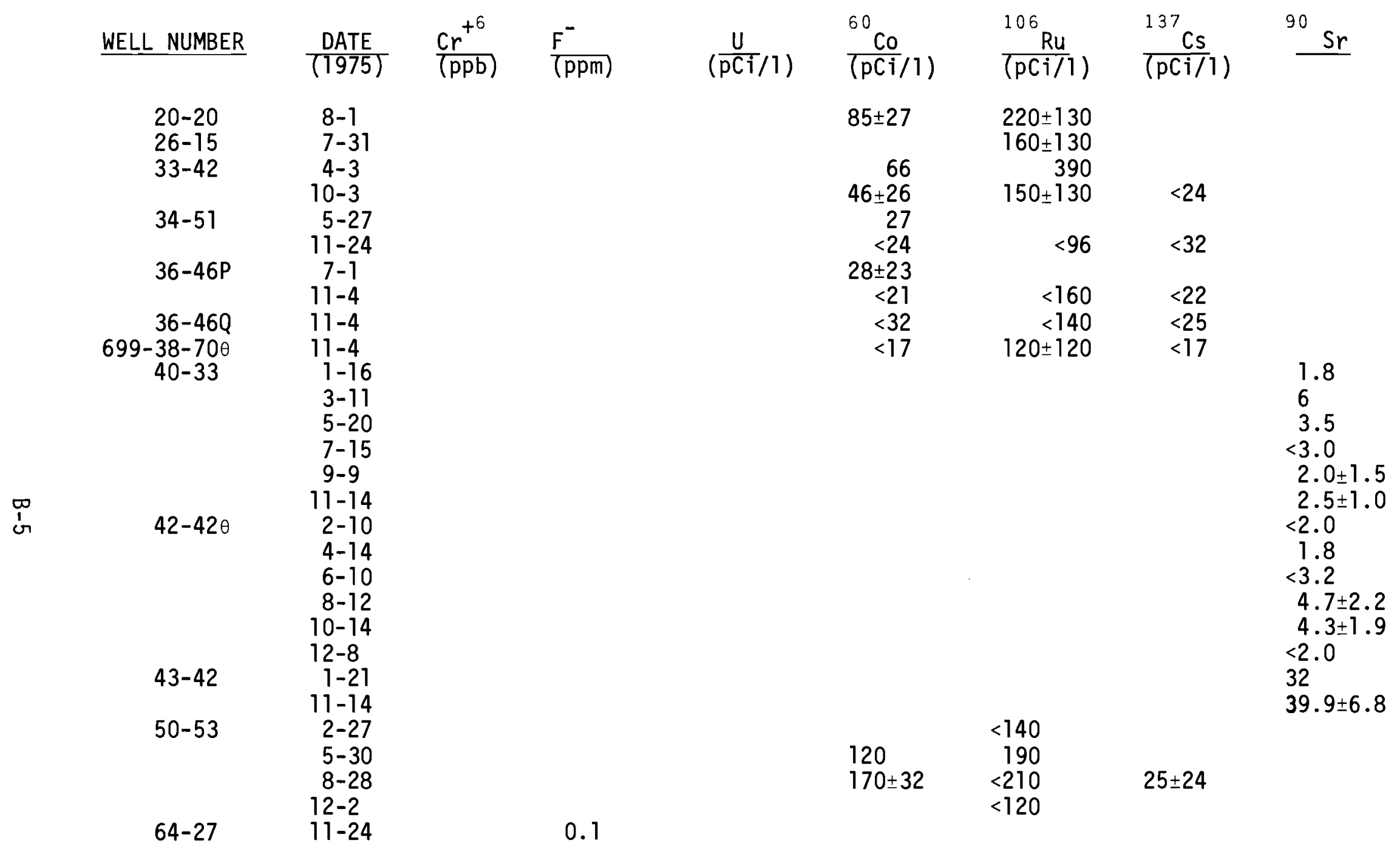


APPENDIX C

SPECTROGRAPHIC AND RADIOCHEMICAL ANALYSES FROM VARIOUS WELLS SAMPLED 


\section{APPENDIX C}

SPECTROGRAPHIC AND RADIOCHEMICAL ANALYSES FROM VARIOUS WELLS SAMPLED JUNE 1975

ANALYSES BY U.S.G.S. LABORATORY, DENVER, COLORADO

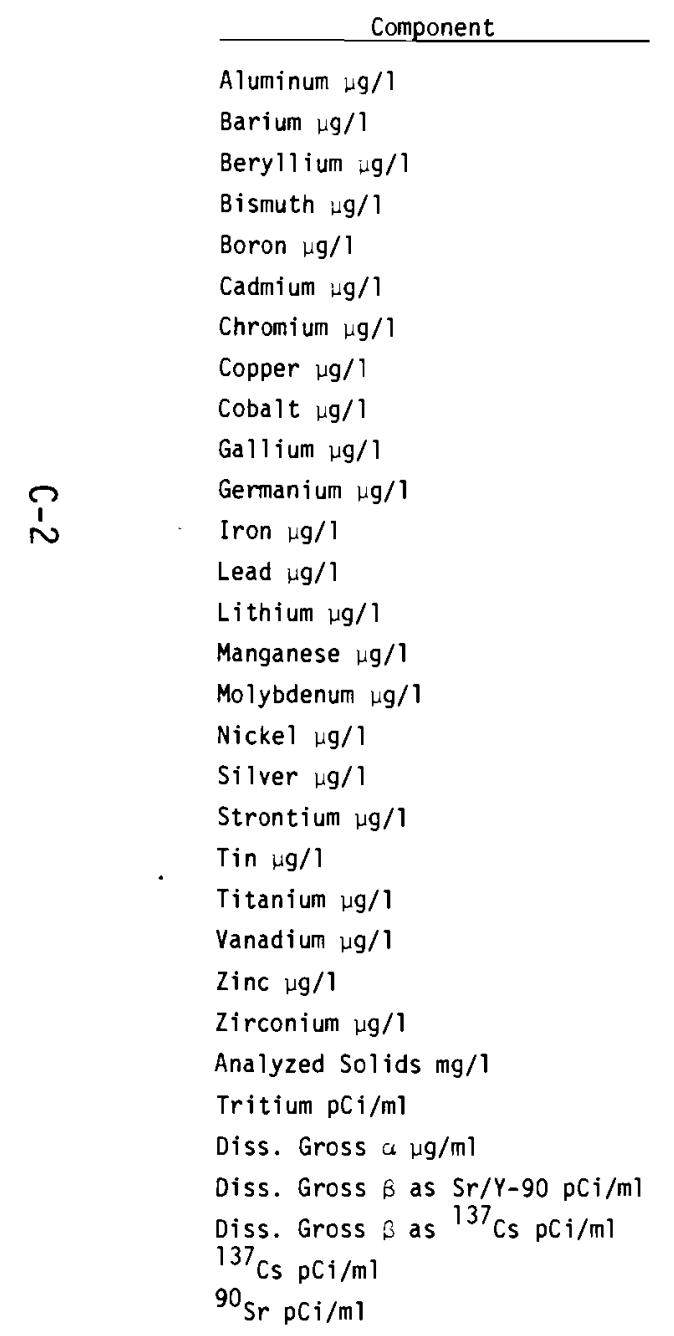

Well 699- Well 699- Well 699- Well 699- Well 699- Well 699- Well 699- Well 699- Well 699- Well 699- Well 699$40-1 \quad \frac{S 6-E 4 D}{33-42} \stackrel{15-15 B}{75} \frac{50-42}{41-23} \stackrel{9-E 2}{32} \frac{32-22}{17-5} \frac{8-32}{49-79}$

\begin{tabular}{|c|c|c|}
\hline 130 & 30 & 75 \\
\hline 40 & 64 & 37 \\
\hline$<.4$ & $<.5$ & $<.5$ \\
\hline$<2$ & $<2$ & $<2$ \\
\hline 16 & 20 & 30 \\
\hline$<3$ & 10 & 30 \\
\hline 3 & $<1$ & 5 \\
\hline 22 & 4 & 25 \\
\hline$<2$ & $<2$ & $<2$ \\
\hline$<.8$ & $<1$ & $<1$ \\
\hline$<2$ & $<2$ & $<2$ \\
\hline 300 & 330 & 1700 \\
\hline 4 & 4 & 10 \\
\hline 6 & 7 & 7 \\
\hline 17 & 480 & 50 \\
\hline 2 & 5 & 7 \\
\hline 2 & 5 & 5 \\
\hline$<.2$ & $<.2$ & $<.2$ \\
\hline 220 & 220 & 200 \\
\hline$<2$ & $<2$ & $<2$ \\
\hline 12 & $<1$ & 4 \\
\hline 15 & 2 & 11 \\
\hline 10 & 1600 & 20 \\
\hline$<4$ & $<4$ & $<5$ \\
\hline 351 & 410 & 435 \\
\hline 84 & 2.7 & 1100 \\
\hline 31 & 8.6 & 11 \\
\hline .025 & .0085 & .12 \\
\hline .031 & .011 & .16 \\
\hline .0032 & .0002 & .002 \\
\hline$<.0001$ & $<.0001$ & $<.0001$ \\
\hline
\end{tabular}

\begin{tabular}{|c|c|}
\hline 5 & 230 \\
\hline 51 & 48 \\
\hline$<.4$ & $<.4$ \\
\hline$<2$ & $<2$ \\
\hline 20 & 16 \\
\hline$<4$ & $<3$ \\
\hline$<1$ & $<.8$ \\
\hline 2 & 10 \\
\hline$<2$ & $<2$ \\
\hline$<1$ & $<.7$ \\
\hline$<2$ & $<2$ \\
\hline 10 & 1500 \\
\hline 3 & 5 \\
\hline 6 & 6 \\
\hline 40 & 23 \\
\hline 3 & 5 \\
\hline$<2$ & 3 \\
\hline$<.2$ & $<.2$ \\
\hline 200 & 190 \\
\hline$<2$ & $<2$ \\
\hline$<1$ & 40 \\
\hline 10 & 18 \\
\hline 100 & 100 \\
\hline$<4$ & $<4$ \\
\hline 379 & 330 \\
\hline$<.48$ & $<.48$ \\
\hline 16 & 13 \\
\hline .0087 & .01 \\
\hline . 011 & .013 \\
\hline$<.0001$ & .0006 \\
\hline$<.0001$ & $<.0001$ \\
\hline
\end{tabular}

14
33
$<.5$
$<2$
20
$<4$
1
2
$<2$
$<1$
$<2$
350
$<2$
5
25
7
3
$<.2$
260
$<2$
$<1$
10
30
$<5$
457
890
24
.06
.074
.0013
$<.0001$

48
$<.4$
$<2$
20
$<3$
$<.8$
7
$<2$
$<.7$
$<2$
250
5
10
140
7
2
$<.2$

44
$<.5$
$<3$
15
$<5$
4
5
$<3$
$<1$
$<3$
250
4
5
12
3
3
$<.3$

67
$<.5$
$<2$
15
$<4$
1
4
$<2$
$<1$
$<2$
4500
10
5
55
$<1$
5
$<.2$
190

130

$\begin{array}{ll}190 & 270 \\ <2 & <3\end{array}$

$5 \quad 5$

$<1 \quad 10$

17

$<4$

$\begin{array}{lr}330 & 471 \\ <.48 & 1500\end{array}$

.018

13

$190 \quad 190<2<$

$<2<2<150$

$25<1 \quad 10$

$8 \quad 4 \quad 13$

$50 \quad 10 \quad 45$

$<5<4<4$

$\begin{array}{lrr}426 & 363 & 384 \\ <.48 & <.48 & <.48\end{array}$

$\begin{array}{lll}12 & 5.6 \quad 5.6\end{array}$

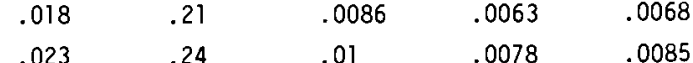

$\begin{array}{lllll}.0002 & .0048<.0001<.0001<.0004\end{array}$

$<.0001<.0001<.0001<.0001<.0001$ 


\section{APPENDIX C}

WATER QUALITY RESULTS FROM VARIOUS WELLS SAMPLED JUNE 1975 ANALYSIS BY CENTRAL LABORATORY, USGS, SALT LAKE CITY, UTAH

\begin{tabular}{|c|c|c|c|c|c|c|c|c|c|c|c|}
\hline Qualy ty Component & $\begin{array}{c}\text { Hell } 699- \\
40-1 \\
\end{array}$ & $\begin{array}{l}\text { He } 11 \text { 699- } \\
\text { S6-E40 } \\
\end{array}$ & $\begin{array}{l}\text { Well } 699- \\
33-42 \\
\end{array}$ & $\begin{array}{l}\text { Wel1 699- } \\
15-158 \\
\end{array}$ & $\begin{array}{r}\text { Wel1 } 699- \\
50-42 \\
\end{array}$ & $\begin{array}{l}\text { Wel1 } 699- \\
41-23 \\
\end{array}$ & $\begin{array}{l}\text { Heli } 699- \\
9-E 2 \\
\end{array}$ & $\begin{array}{c}\text { Hel1 } 699- \\
32-22 \\
\end{array}$ & $\begin{array}{l}\text { We } 11699- \\
17-5 \\
\end{array}$ & $\begin{array}{l}\text { Wel1 } \\
\qquad 8-32 \\
\end{array}$ & $\begin{array}{r}\text { Well } 699- \\
49-79 \\
\end{array}$ \\
\hline 11k, T & 120 & 147 & 107 & 123 & 106 & 108 & 131 & 105 & 106 & 123 & 94 \\
\hline sentc 01ssolved & 4 & 1 & 1 & 4 & 4 & 2 & 10 & 3 & 4 & 1 & 0. \\
\hline Icarbonate & 146 & 179 & 131 & 150 & 129 & 132 & 160 & 128 & 129 & 150 & 114 \\
\hline romide & 0.1 & 0.2 & 0.1 & 0.1 & 0.1 & 0 & 0 & 0.1 & 0.1 & 0.1 & 0.3 \\
\hline Icfum Dissolved & 40 & 45 & 41 & 47 & 3 & 48 & 24 & 53 & 61 & 40 & 14 \\
\hline
\end{tabular}

Calcium Dissolved

Chloride Dissolved

Chromtum 01ssolved

Chromin Hexavalent

Color

Conductivity

Coppor O1ssolved

Cyantde

Fluoride Dissolved

Hardness Noncarb

Hardness Total

Hydroxide

Iodtde

Iron Otssolved

Iron Ferrous

Magnesium Oissolved

Nitr. $\mathrm{NO}_{2}$ as $\mathrm{NO}_{2}$ Diss

$\mathrm{Nitr} . \mathrm{NO}_{3}$ as $\mathrm{NO}_{3}$ Oiss

Nitr. $\mathrm{NH}_{4}$ as $\mathrm{N}$ Tot

Nitr. $\mathrm{NO}_{2}$ as $\mathrm{N}$ Tot

Nitr. $\mathrm{NO}_{3}$ as $\mathrm{N}$ Diss

$\mathrm{NO}_{2}+\mathrm{NO}_{3}$ as $\mathrm{N}$ Diss

Phosphorus tot as

Potassium 01ss

Residue Diss Calc Sum

Residue Diss Ton/Aft

SAR

Se lenium Oissolved

Siltca D1ssolved

Sodium Dissolved

Sodium Percent

Sulfate Dissolved

Turbidity (JTV)

$\begin{array}{ccccc}6.9 & 3.4 & 3.1 & 6.0 & 11 \\ 0 & 10 & 10 & 0 & 10 \\ 2 & 0 & 0 & 0 & 0 \\ 0 & 5 & 4 & 2 & 2 \\ 357 & 416 & 448 & 408 & 330 \\ 47 & 0 & 30 & 1 & 22 \\ 0 & 0 & 0 & 0 & 0 \\ 0.4 & 0.4 & 0.6 & 0.4 & 0.5 \\ 25 & 15 & 48 & 33 & 21 \\ 150 & 160 & 160 & 160 & 130 \\ 0 & 0 & 0 & 0 & 0 \\ 0 & .01 & 0 & 0 & 0 \\ 180 & 130 & 730 & 20 & 970 \\ 190 & 100 & 560 & 30 & 700 \\ 11 & 12 & 13 & 9.3 & 12 \\ .03 & .03 & 0 & 0 & 0 \\ 24 & 6.6 & 49 & 16 & 3.1 \\ 0 & .01 & 0 & .04 & 0 \\ .01 & .01 & 0 & 0 & 0 \\ 5.4 & 1.5 & 11 & 3.6 & .71 \\ 5.4 & 1.5 & 11 & 3.6 & .71 \\ 7.7 & 7.5 & 7.7 & 7.7 & 7.8 \\ .07 & .02 & .03 & .05 & .03 \\ 6 & 6.6 & 6.9 & 7.2 & 5.9 \\ 241 & 269 & 250 & 267 & 229 \\ .33 & .30 & .34 & .36 & .31 \\ 0.6 & 0.8 & 1.1 & 0.7 & 0.7 \\ 2 & 2 & 3 & 7 & 5 \\ 37 & 32 & 38 & 30 & 44 \\ 17 & 22 & 31 & 20 & 18 \\ 20 & 22 & 29 & 21 & 23 \\ 26 & 2.2 & 2.4 & 57 & 39 \\ 4 & 5 & 39 & 4 & 13 \\ & & & & \end{array}$

*All units in mg/1 unless otherwise noted. 
APPENDIX D

SPECIAL ANALYSES FOR QUALITY ASSURANCE 
APPENDIX D

Special Analyses for Quality Assurance

\begin{tabular}{|c|c|c|c|c|c|c|c|}
\hline Well \# & Date & $\begin{array}{c}\mathrm{pCr} / \mathrm{ml} \\
\text { Beta }\end{array}$ & $\underset{3 / \mathrm{H}}{\mathrm{pCi}}$ & $\begin{array}{l}\mathrm{pCj} / \mathrm{ml} \\
{ }_{60} \mathrm{COO}\end{array}$ & $\begin{array}{l}\mathrm{pCj} / \mathrm{m} \ell \\
{ }_{06} \mathrm{Ru}\end{array}$ & $\begin{array}{l}\mathrm{pCi} / \mathrm{m} \ell \\
{ }_{137} \mathrm{Cs}\end{array}$ & $\begin{array}{l}\mathrm{ppm} \\
\mathrm{NO}_{3}^{-}\end{array}$ \\
\hline $699-\$ 3-25$ & $10-28-75$ & & $\begin{array}{l}<0.88 \\
<1.0\end{array}$ & & & & $\begin{array}{l}<0.5 \\
<0.5\end{array}$ \\
\hline $699-37-82 A \theta$ & $10-28-75$ & & $\begin{array}{l}0.92 \pm 0.88 \\
1.3 \pm 0.92\end{array}$ & & & & $\begin{array}{l}55 \\
1.4\end{array}$ \\
\hline $699-15-15 B$ & $10-28-75$ & $\begin{array}{l}<0.08 \\
<0.08\end{array}$ & $\begin{array}{l}<1.0 \\
<1.1\end{array}$ & & & & 13 \\
\hline $699-38-70$ & $11-4-75$ & $\begin{array}{l}0.23 \\
0.23\end{array}$ & $\begin{array}{l}34 \\
36\end{array}$ & $\begin{array}{c}<0.017 \\
.033 \pm .022\end{array}$ & $\begin{array}{l}0.12 \pm 0.12 \\
0.16 \pm 0.12\end{array}$ & $\begin{array}{c}<0.017 \\
0.018 \pm 0.021\end{array}$ & $\begin{array}{l}260 \\
180\end{array}$ \\
\hline $699-49-57$ & $2-27-76$ & $\begin{array}{l}1.2 \\
1.3\end{array}$ & $\begin{array}{l}340 \\
310\end{array}$ & & & & $\begin{array}{l}200 \\
190\end{array}$ \\
\hline $699-32-77$ & $2-26-76$ & $\begin{array}{l}<0.08 \\
<0.075\end{array}$ & $\begin{array}{l}<1.2 \\
<1.3\end{array}$ & & & & $\begin{array}{l}6.4 \\
6.2\end{array}$ \\
\hline $699-49-55$ & $2-27-76$ & $\begin{array}{l}<0.08 \\
<0.075\end{array}$ & $\begin{array}{l}<1.4 \\
<1.4\end{array}$ & & & & $\begin{array}{l}4.2 \\
4.1\end{array}$ \\
\hline $699-35-70$ & $2-26-76$ & $\begin{array}{l}0.085 \\
0.13\end{array}$ & $\begin{array}{l}8600 \\
8300\end{array}$ & & & & $\begin{array}{l}20 \\
16\end{array}$ \\
\hline
\end{tabular}




\section{DISTRIBUTTION}

No. of

Copies

OFFSITE

A. A. Churm

ERDA Chicago Patent Group

9800 S. Cass Avenue

Argonne, IL 60439

D. H. Slade

ERDA Div. of Biomedical

and Environmental Research

Washington, DC 20545

A. A. Schoen

ERDA Divison of Operational Safety

Washington, DC 20545

W. R. Wright, Jr.

ERDA Division of Nuclear

Fuel Cycle and Production

Washington, DC 20545

27 ERDA Technical Information Center

5 C. V. Smith

EPA Region $X$

1200 Sixth Avenue

Seattle, WA 98101

M. W. Lammering

EPA Office of Water Programs

5555 Ridge Avenue

Cincinnati, $\mathrm{OH} 45213$

R. C. Scott

EPA Office of Water Programs

760 Market Street

San Francisco, CA 94102

C. Hall

Washington State Dept. of Social and Health Services

Smith Tower

Seattle, WA 98104
No. of

Copies
T. Strong

Washington State Dept. of Social and Health Services

Smith Tower

Seattle, WA 98104

Battelle Memorial Institute

Columbus, $\mathrm{OH}$

\section{ONSITE}

16 ERDA Richland Operations Office

0. J. Elgert(2)

R. L. Ferguson

J. A. Fernandez(5)

P. G. Holsted

P. G. Rhoades

J. L. Rhoades

M. W. Tiernan(5)

9 Atlantic Richfield Hanford

G. E. Backman

D. J. Brown

R. A. Deju

R. E. Gephart

G. L. Hanson

R. E. Isaacson

K. R. Price

B. J. Saueressig

ARHCO File

1 Hanford Environmental Health Foundation

R. G. Anderson 
No. of

Copies

5 United Nuclear Industries, Inc.

T. E. Dabrowski

A. E. Engler

N. R. Miller

W. G. Westover

UNI File

2 Washington Public Power Supply System

F. E. Owen

D. D. Tilson

1 Westinghouse-Hanford Company - HEDL

R. B. Hall

32 Battelle-Northwest

D. B. Cearlock

J. P. Corley

J. R. Eliason (10)

J. J. Fix

L. J. Kirby

H. V. Larson

D. A. Myers (10)

J. R. Raymond

J. H. Soehnlein

C. M. Unruh

Technical Information (3)

Technical Publications 
See report for actual sized maps. 


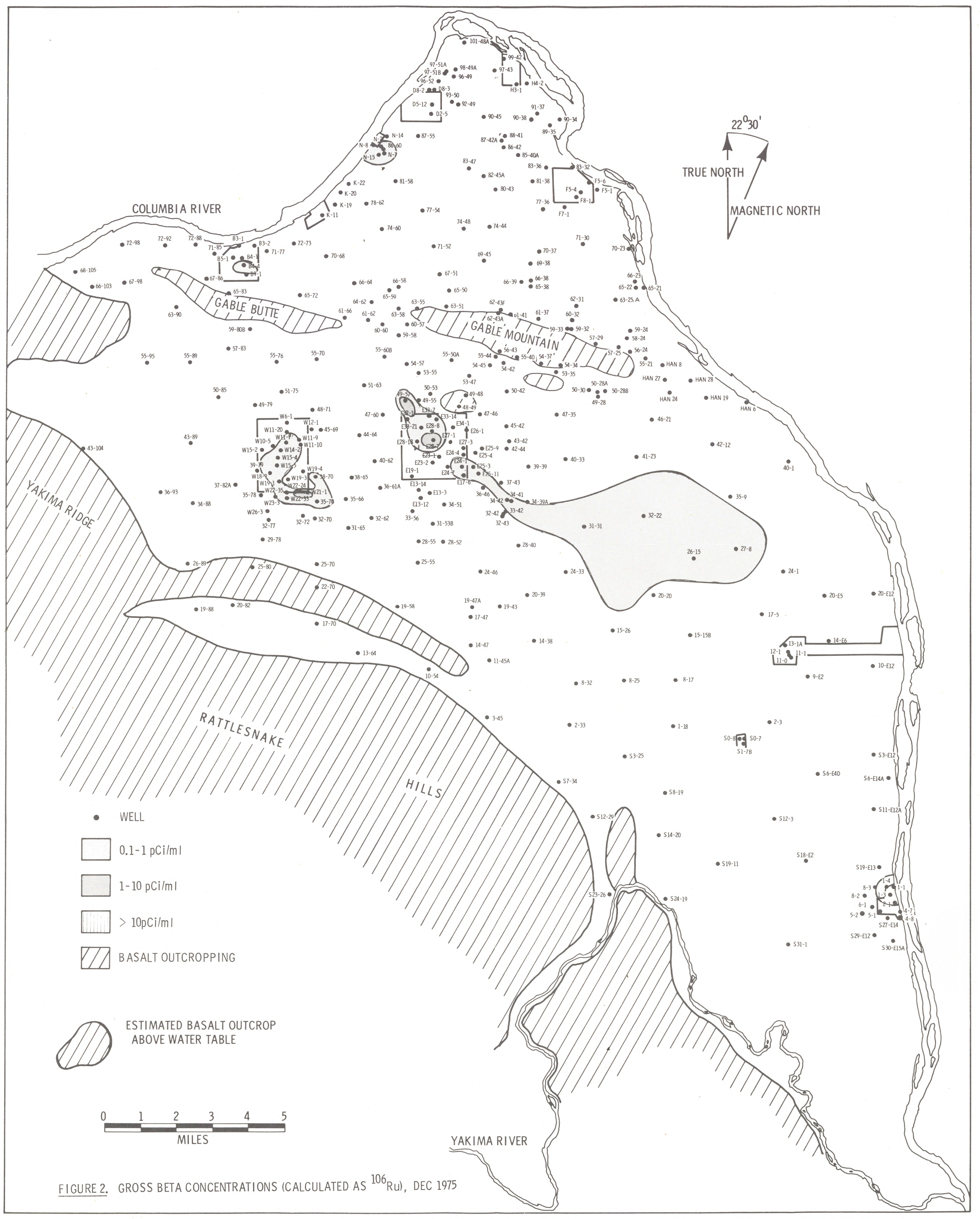




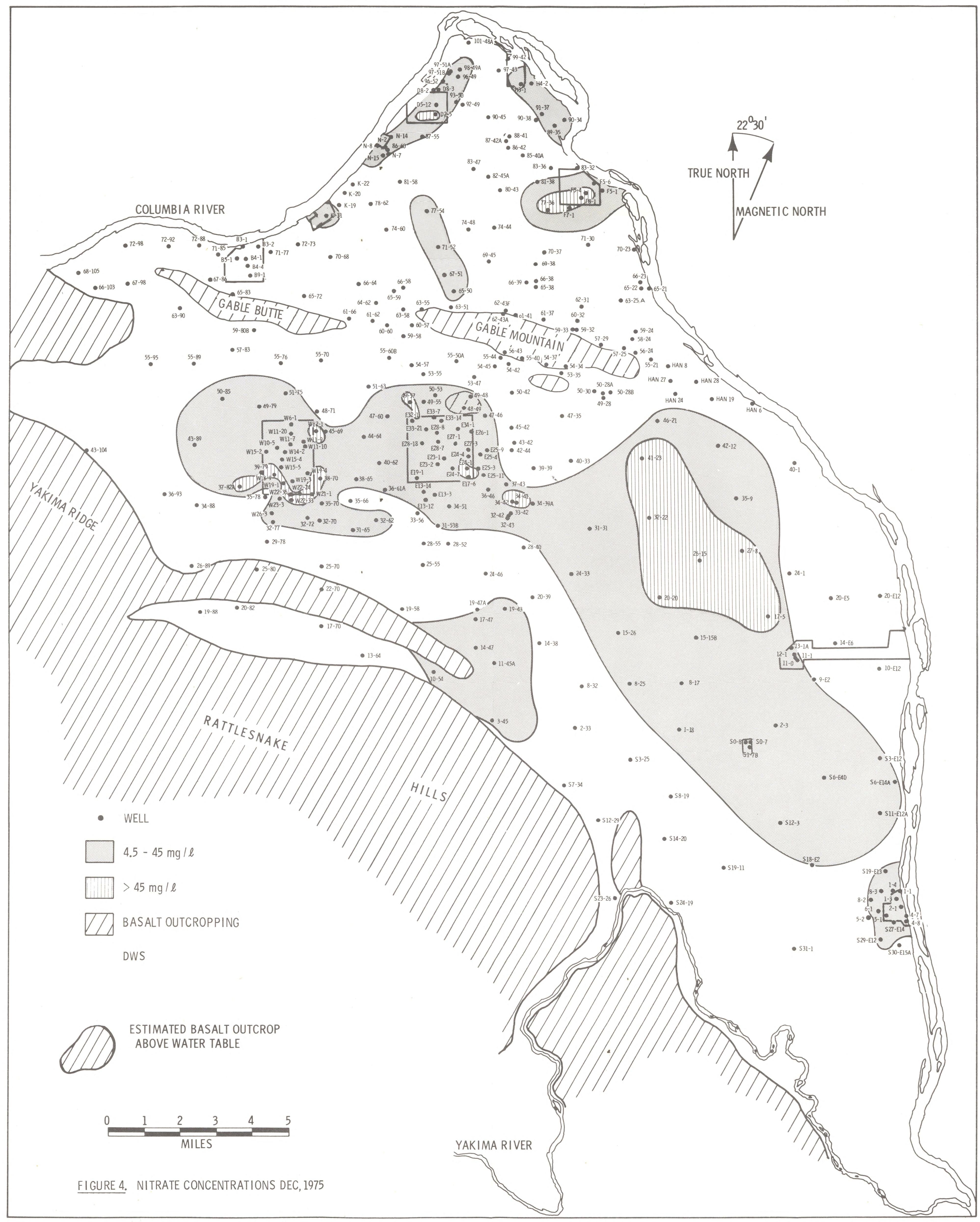



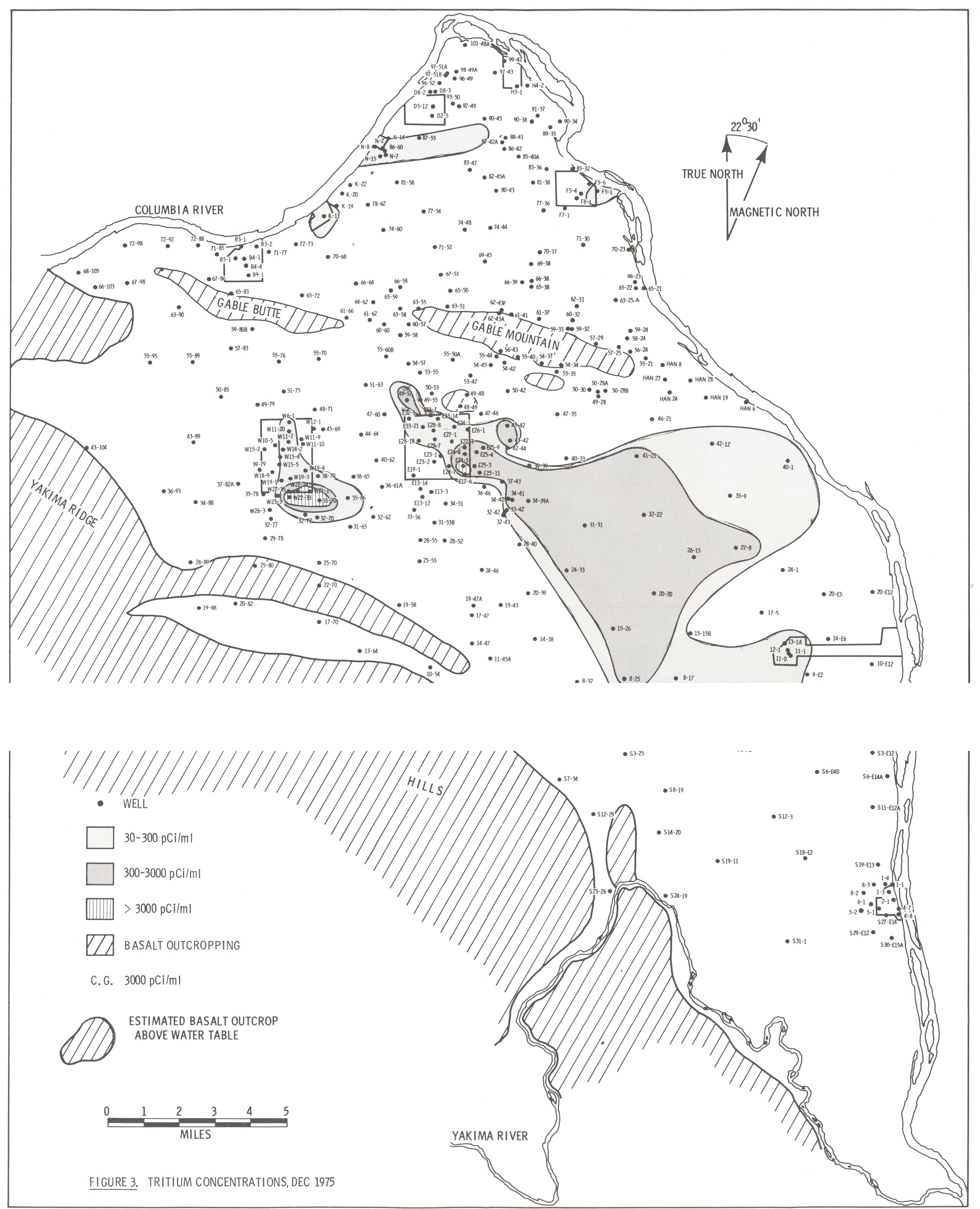


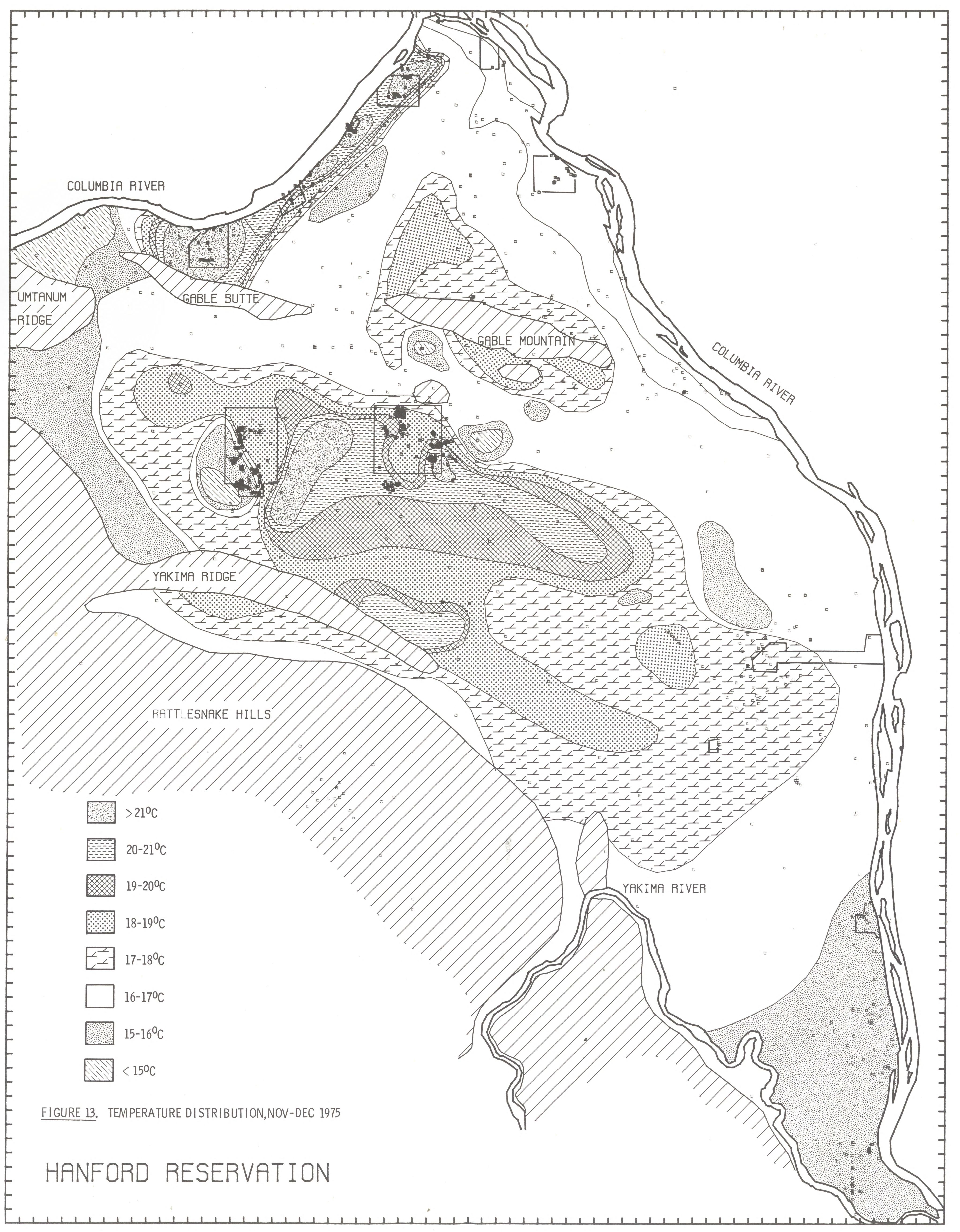

